\title{
Formação territorial enquanto instrumento de afirmação das fronteiras entre São Paulo e Minas Gerais nos séculos XVIII e XIX. A freguesia de N. S. da Conceição do Bom Sucesso do Rio Pardo
}

Dossier Rede URbana E DEFInIÇÃo das Fronteiras PAULISTAS

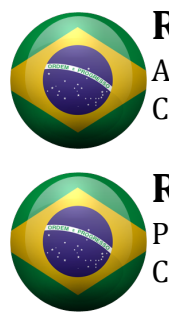

\section{Rafael Augusto Silva Ferreira}

Arquiteto e Urbanista, Mestrando do Programa de Pós-graduação da Pontifícia Universidade Católica de Campinas. Campinas [SP] Brasil <ferreiraprojetos1@gmail.com>.

\section{Renata Baesso Pereira}

Professora Doutora, Titular do Programa de Pós-graduação em Urbanismo (POSURB - PUC Campinas). Campinas [SP] Brasil <renata.baesso@puc-campinas.edu.br $>$.

\section{Resumo}

O presente artigo discute a formação de parte da região nordeste paulista a partir da criação da freguesia de Nossa Senhora da Conceição do Bom Sucesso do Rio Pardo (Caconde), elucidando o processo de ocupação do território, enquanto afirmação da fronteira entre as Capitanias e, posteriormente, Províncias de São Paulo e Minas Gerais. 0 trabalho parte da definição teórico-metodológica da constituição de rede de cidades, enquanto forma de consolidar a ocupação dos territórios no Brasil Colônia e Império. A gênese dos conflitos ligados à definição da fronteira na região envolve os novos descobertos auríferos, a abertura de caminhos e a criação de novas freguesias e vilas. 0 trabalho adota uma abordagem macrorregional para compreender as relações territoriais, definindo a formação da paisagem a partir da sobreposição dos diferentes tempos históricos.

\section{Palavras-chave}

Formação territorial. Rede urbana. Território paulista e mineiro. Fronteiras. Paisagem.

\section{Territorial formation as an instrument for the assertion of the borders between São Paulo and Minas Gerais during the 18th and 19th centuries. The parish of N. S. da Conceição do Bom Sucesso do Rio Pardo}

\begin{abstract}
This article discusses the formation of a part of northeastern São Paulo from the creation of the parish of Nossa Senhora da Conceição do Bom Sucesso do Rio Pardo (Caconde), elucidating the process of occupation of the territory to affirm the frontier between the Capitanias and later the Provinces of São Paulo and Minas Gerais. The work is based on the theoretical-methodological definition of the constitution of a network of cities as a way of consolidating the occupation of the territories in Brazil during the Colonial and Imperial periods. The genesis of conflicts related to the definition of the border in the region involves the new gold discoveries, the opening of roads, and the creation of new parishes and villages. The work adopts a macroregional approach to understand territorial relations, defining the formation of the landscape based on the overlapping of different historical times.
\end{abstract}

\section{Keywords}

Territorial formation. Urban network. Territory of Sao Paulo and Minas Gerais. Frontiers. Landscape. 


\section{Introdução: os conceitos de rede urbana e paisagem}

A formação do território paulista deve ser vista como um longo processo histórico, iniciado no século XVI com a fundação da vila de São Paulo de Piratininga, núcleo de povoamento apartado da lógica da povoação do litoral brasileiro, isolado por detrás da muralha geográfica da Serra do Mar. Fundada por ação dos jesuítas, exploradores dos saberes indígenas, São Paulo nasceu do entroncamento de antigas trilhas de gentios, cunhadas em período pré-cabralino, pontas de lança no desbravar dos sertões.

No presente artigo, ao investigar o processo de formação do território paulista, iremos nos ater ao movimento de dilatação e retração da fronteira política pela criação de uma rede urbana hierarquizada, conectada por caminhos e trilhas que nasceram com os processos de desbravamentos nos séculos XVIII e XIX, com ênfase na porção nordeste do atual Estado de São Paulo em sua fronteira com Minas Gerais.

Para Jucá Neto, "a estratégia encontrada no Brasil foi a fundação de vilas¹. Com o território pontuado com vilas, garantia-se e confirmava-se o estabelecimento da autoridade e da soberania lusitana nas áreas ocupadas". (2012, p. 113). De acordo com definição do autor, que se apoia na noção de rede ao tratar do conceito de território, os termos das vilas seriam uma fronteira abstrata, fronteira essa que veremos, irá sempre utilizar de referenciais geográficos para seu balizamento.

A rede urbana, na definição de Milton Santos, compreende duas matrizes, de ordem material e social, sob pontos de atração e difusão, "que é o caso das redes urbanas" (2002, p. 263). Adotamos a definição de Santos, no que diz respeito à conceituação da rede enquanto seu enfoque "genético", que entende a formação da mesma como um processo. Assim, entende-se os vários pontos nodais dispersos pelo território (fazendas, registros, povoados, bairros rurais, capelas, pousos, barreiras) se estruturando em diferentes tempos, operando com diferentes finalidades, mesmo que muitos não existam na atualidade. Reconstituir a rede, segundo o autor, seria fundamental "se queremos entender como uma totalidade a evolução de um lugar" (Santos, 2002, p. 263). 0 enfoque de Milton Santos entende que uma rede também é política e social, uma vez que as unidades que a compõem são pessoas, criando relações materiais, transmitindo mensagens e realizando trocas. Nesse sentido, a rede também é um conceito abstrato e, as fronteiras sempre abertas ${ }^{2}$, pois embora delimitadas por referenciais geográficos claros (rios, formações rochosas, serras, montanhas), sua real demarcação dá-se ao sabor das ocupações e conquistas efetivas. A formação da rede urbana, e consequente-

\footnotetext{
${ }^{1}$ As vilas são, nos períodos colonial e imperial, núcleos urbanos dotados de uma unidade política e administrativa autônoma, ou seja, constituindo a sede de um município. 0 ato de se elevar uma povoação, ou freguesia, ao status de vila é o de lhe conceder a autonomia administrativa. A vila passa então a ser composta de uma Câmara, cujos membros escolhidos por voto indireto, representariam os três poderes. Com a ereção à vila, é demarcado o termo, delimitação do território da nova sede de municipalidade, implicando nos limites da sua atuação e jurisdição. As outras freguesias ou povoados que por ventura estivessem dentro dos limites do termo da vila, estariam sujeitas à legislação da mesma. Diferente do termo, o rossio é uma demarcação feita a partir do centro definido pelo pelourinho, em geral de formato quadrado, medindo um quarto de légua de lado. 0 rossio constitui a porção de terras destinada ao sustento da Câmara, como terra pública e atendia, segundo Murilo Marx, a dois fins principais: " a utilização comunal, sobretudo para pasto e obtenção de lenha, e a reserva de terras para a expansão da vila, seja por meio da concessão de datas, seja pela extensão de seu arruamento" (Marx, 1991, p. 81).
}

2 O conceito de fronteira aberta é desenvolvido na obra de Beatriz Piccolotto Siqueira Bueno, no trabalho "Dilatação dos confins: caminhos, vilas e cidades na formação da Capitania de São Paulo (1532-1822) ", onde a autora explora o papel da rede urbana enquanto conquista dos sertões, formação territorial: "0 território, com contornos e limites precisos é uma categoria histórica, construída socialmente. Para além das fronteiras naturais, a fronteira política é sempre uma linha abstrata e convencionada [grifo nosso] por alguns. Às zonas interiorizadas dava-se o nome 'sertão' [...]". (Bueno, 2009, p. 251-252). Para Cláudia Damasceno Fonseca, “o termo 'sertão', que designa o interior desconhecido, selvagem e mítico da colônia, pode ser ainda considerado como um dado preexistente à colonização, ou ainda como o negativo do processo de povoamento e urbanização" (Fonseca, 2011, p. 51). No presente artigo, procuraremos demostrar contudo, a movimentação e reais conflitos de litígio de fronteira ocorridos no "sertão do Rio Pardo", pelo estabelecimento de registros, pousos, e núcleos de povoamento como instrumentos de afirmação da posse do território. Para Cláudia Damasceno Fonseca ainda, "o sertão colonial é, ao contrário, um espaço de perpétuo vir a ser: sua conversão em território se faz à medida que o povoamento avança e se intensifica. 0 qualitativo 'liminar', tomado no seu sentido antropológico, também parece bastante adequado para descrever a realidade deste espaço, caracterizado por uma relativa e temporária indefinição, a qual antecede ou acompanha sua passagem a uma nova categoria" (Fonseca, 2011, p. 54). 
mente a definição de suas fronteiras não ocorre apenas como objeto geográfico e, reforçando a afirmação de Milton Santos: "são um fato econômico, financeiro, fiscal, diplomático, militar, além de político" (2002, p. 265).

Lobato Corrêa define o conceito de rede urbana, destacando a necessidade de identificar, sobre os vários pontos físicos no território, uma economia de mercado que vise as atividades de comércio. Isso pressupõe, certamente, uma divisão mínima territorial do trabalho. 0 argumento do autor está na afirmação de que esses pontos, pela concentração da atividade de comercialização, dariam origem a outras atividades diferentes das iniciais, sendo responsáveis primeiro pela diversificação das trocas no território e, segundo, pela geração de núcleos urbanos de povoamento, onde ocorressem tais atividades. 0 terceiro aspecto, segundo o autor, é a articulação estabelecida entre os pontos:

A terceira condição refere-se ao fato da existência de um mínimo de articulação existente entre os núcleos anteriormente referidos, articulação que se verifica no âmbito da circulação, etapa necessária para que a produção exportada e importada realize-se plenamente, atingindo os mercados consumidores (Corrêa, 1989, p. 7).

Nesse contexto apresentado por Corrêa, a rede reforça as relações econômicas e sociais do território, figurando realmente uma representação sócio espacial. Segundo o mesmo, os estudos mais numerosos e tradicionais sobre a rede urbana, encaram os aspectos relativos à hierarquia dos núcleos urbanos, "derivam de questionamentos sobre o número, tamanho e distribuição das cidades e, implicitamente, sobre a natureza da diferenciação entre elas (Corrêa, 1989, p. 20). É sobre essa definição que trabalhamos o presente artigo, tendo como pressuposto a formação de uma rede urbana a partir de núcleos hierarquizados, necessariamente como processo de construção do território e como afirmação das fronteiras entre Minas Gerais e São Paulo. No processo de construção do território, a localização dos vários pontos de estabelecimento humano ocorreu ao sabor do tempo, das viagens diárias; um pouso, denominação de uma parada de viajantes ou tropeiros, localizava-se à distância média de uma viagem em relação ao pouso seguinte, dos caminhos que percorreram os sertões desde meados do século XVI, com a fundação de São Paulo dos Campos de Piratininga, até meados do século XVIII com a abertura da Estrada dos Goiases. Na marcha do século XIX, em direção às terras do Oeste Paulista - tema desenvolvido na obra de Pierre Monbeig (1984) as distâncias se ampliaram em virtude do novo meio de transporte empreendido: a ferrovia, que foi a precursora e, em muitos casos, desenhou, verdadeiramente, novos núcleos urbanos no território paulista. O conceito de rede urbana se dá no tempo histórico; ademais é pela sobreposição dos vários caminhos, rotas e fluxos de pessoas que a rede se manifesta, unindo o social ao espaço geográfico. A rede urbana é, portanto, a materialização de uma dada sociedade num tempo definido.

A compreensão da rede nos impõe uma perspectiva macrorregional, transcendendo as fronteiras políticas atuais, em um primeiro momento, para delinear as relações entre os pontos nodais que não obedecem à divisão dos atuais Estados de São Paulo e Minas Gerais. Os estudos recentes sobre a urbanização no período colonial, permitem avançar nos conceitos de urbano e território para além da costumeira atenção depositada na esparsa rede de vilas e freguesias ${ }^{3}$, em meio a sertões totalmente desocupados. A rede urbana compreende, portanto, segundo Beatriz Bueno,

\footnotetext{
${ }^{3}$ A constituição de um povoado, ou arraial (aqui utilizamos este termo para designar toda povoação em emergência do urbano; reunião de moradores em um local demarcado) dependia da doação de uma porção de terra à um santo de devoção. A terra, em outras palavras, passava a pertencer ao santo, e à Igreja o direito de repartir datas (terrenos) destinados aos moradores, quando a capela erigida alcançasse um status maior, sendo sagrada por um padre (cura), tornando-se uma capela curada. Sobre o léxico da ocupação, Cláudia Damasceno Fonseca aponta que "tais núcleos, que não gozavam de autonomia do ponto de vista jurídico-administrativo, eram designados, em Portugal, pelas palavras lugar (lugares) ou aldeia, enquanto na América portuguesa, como se sabe, este último vocábulo adquiriu uma conotação étnica, significando uma povoação indígena [...] Já a palavra povoação, tanto no reino como na colônia, era um termo genérico, que podia se referir a todos os tipos de aglomerações, inclusive às cidades e às vilas." (Fonseca, 2011, p. 28). Como a definição da autora sugere, os termos "povoado" ou "arraial' não indicavam contudo um status urbano dentro da rede, podiam ser quaisquer aglomerados humanos, e na colônia mesmo as vilas e cidades eram por vezes designadas pelo termo "povoado". A necessidade de um amparo civil mais próximo, e a "ascensão de toda uma região inóspita, ou de ocupação mais antiga e em expansão, ao novo status de paróquia ou freguesia" (Marx, 1991, p. 18) era a garantia ao registro civil, de batismo e morte, e suas implicações jurídicas. Com a criação da freguesia, a mesma passaria a compor um termo (limite territorial) que estaria subordinado por sua vez ao termo da vila a qual a freguesia pertencesse. As criações de freguesias obedeciam ao disposto nas “Constituições Primeiras do Arcebispado da Bahia”, redigidas em 1707 e publicadas em 1719, que instruíam sobre a posição das igrejas, sua construção e a forma dos núcleos urbanos que se formavam. Segundo Murilo Marx: “a ereção do lugarejo, da 'capela', em paróquia, sujo nome corriqueiro tradicional foi freguesia e que constituía o módulo da organização eclesiástica, como que a sua unidade territorial” (1991, p. 27).
} 
"qualquer vestígio de localidade indicativa de presença humana irradiada de demandas urbanas" (Bueno, 2016, p. 826). A autora, ao descrever uma série de pesquisas recentes, amplia a noção do próprio conceito de sertão, enquanto um local ermo e desabitado, para uma rede formada por pontos diversos conformando uma macrorregião. Ainda segundo Bueno, "esses estudos permitem alargar o conceito de núcleo urbano propriamente dito, ao demostrar que lhes orbitavam um rosário de fazendas e sítios que alimentavam mercados distantes" (Bueno, 2016, p. 826).

Além do conceito de rede urbana, o presente trabalho também se apoia no conceito de paisagem. É em Santos (2002) que definimos a noção de paisagem, para conceitua-la e diferencia-la da noção de espaço:

[...] a paisagem é o conjunto de formas que, num dado momento, exprimem as heranças que representam as sucessivas relações localizadas entre homem e natureza. $O$ espaço são essas formas mais a vida que as anima (Santos, 2002, p. 103).

A paisagem é, portanto, o conjunto de formas naturais e artificiais modificados pelo homem, as quais Milton Santos denomina "configuração territorial". A paisagem seria para o autor, a porção da configuração territorial possível de ser abarcada pela visão. 0 espaço é a construção atual, ou seja, a função que as diferentes formas assumem no presente, diferente da paisagem que, para nós é sempre entendida como uma construção transtemporal, histórica.

Tendo como referência tais autores, constituindo um quadro teórico-metodológico sobre a formação territorial brasileira, é possível aplicar os conceitos demonstrados sobre o recorte espaçotemporal que engloba uma parcela da formação da região nordeste paulista. A pesquisa também demonstra os processos de desmembramentos territoriais que originaram os atuais municípios da região, a partir da vila de Mogi-Mirim elevada em 1769. 0 objetivo do presente trabalho é o de demonstrar a formação do território paulista a partir da vila de Mogi-Mirim (1769) e Casa Branca (1841), com foco sobre a antiga freguesia de Nossa Senhora da Conceição do Bom Sucesso do Rio Pardo (atual município paulista de Caconde), e da mesma forma, a política de definição das fronteiras, cujos litígios iniciados no século XVIII, iriam ser resolvidos somente nos anos 1935 e 1936, com o governo Vargas ${ }^{4}$.

Desde as publicações do Instituto Geográfico e Cartográfico sobre a formação dos municípios paulistas - "Quadro do desmembramento territorial-administrativo dos municípios paulistas" (1995) e "Municípios e Distritos" (2011) - muito se tem avançado sobre a compreensão desse processo, à luz de eventos que transformaram o espaço geográfico que hoje conhecemos. Assim, nos debruçamos sobre uma pequena parte dessa formação: os municípios originários do desmembramento da vila de Mogi-Mirim, no século XIX, a partir da elevação da vila de Casa Branca (1841), estudando com maior atenção a rede urbana formada a partir dos conflitos de fronteira envolvendo a região de Caconde, primeira freguesia criada no Sertão do Rio Pardo ${ }^{5}$, em 1775, como estratégia do governo de São Paulo para tomar posse dos novos descobertos auríferos da região.

Dialogando com autores que versam sobre o processo de construção territorial paulista, como Nilson Ghirardello (2010), Carlos Bacellar e Lucila Reis Brioschi (1999) e Nestor Goulart Reis (2013), para citar alguns, buscamos relacionar a formação do território, em nosso recorte espacial, com os processos que definiram as fronteiras, estabeleceram jurisdições e, acima de tudo, conformaram uma paisagem que carece de políticas e práticas de preservação, de salvaguarda de um patrimônio que transcende fronteiras.

\footnotetext{
${ }^{4}$ No contexto do Estado Novo, promulgado por Getúlio Vargas em 1934, foi celebrado o convênio entre os dois Estados, pelo decreto no 7.168, de 25 de maio de 1935, que constituía uma comissão para o exame e resolução das divisas entre Minas Gerais e São Paulo. 0 término da questão adveio com a Lei no 115/1936 de Minas Gerais, assinada pelo governador mineiro Benedito Valadares Ribeiro, e a Lei no 2.694/1936 assinada pelo governador paulista Armando de Salles Oliveira, ambas com redação idêntica celebrando as novas divisas e pondo fim a questão oriunda desde o século XVIII.

${ }^{5}$ Este artigo é parte integrante da pesquisa de mestrado em Urbanismo, desenvolvida na PUC Campinas, que tem por objetivo compreender a formação do território de Caconde e São José do Rio Pardo, município formado a partir deste, bem como a rede urbana formada pelos caminhos e rotas que ligaram a região ao sul de Minas Gerais, nos interstícios do rural e do urbano.
} 


\section{A formação do território paulista: a gênese dos conflitos de fronteiras}

A ocupação no planalto paulista, em meados do século XVII tinha como limite o morro do Jaraguá, nas proximidades com São Paulo. A única vila fundada para além de São Paulo (elevada à vila em 1560, pela transferência do pelourinho e Câmara da vila de Santo André da Borda do Campo), em 1625, foi Santana de Parnaíba, povoação existente já no início do século XVII. Segundo Nestor Goulart Reis, a povoação, formada em 1624 pela fazenda de Suzana Dias, deu-se pela doação de duzentas braças em quadra de suas terras para a capela de San'Ana, elevada a vila no ano seguinte (Reis, 2013, p. 172).

A capela de Nossa Senhora do Desterro de Jundiaí, próxima ao rio Jundiaí, é elevada à condição de freguesia em 1634, pertencente à Santana de Parnaíba. Jundiaí seria elevada à condição de vila em 1655, tornando-se a única povoação além morro do Jaraguá, estendendo seu termo com jurisdição sobre o território paulista. A fronteira, no entanto, era aberta, uma vez que, antes de 1709, a região pertencia às Capitanias hereditárias, sob domínio dos donatários. Maria Fernanda Derntl aponta para o fato:

Em 1709 as capitanias de São Vicente e Santo Amaro foram adquiridas pela Coroa e desmembradas do Rio de Janeiro, vindo a formar a Capitania geral de São Paulo e Minas do Ouro. A instalação da nova unidade de governo teve também intenção de estabelecer um controle mais efetivo sobre a região mineira e buscar uma solução para as disputas que haviam levado à Guerra dos Emboabas (1707-1709) (Derntl, 2010, p. 55).

A elevação de São Paulo ao status de cidade, em 1711, deve ser vista como uma estratégia da Coroa em unificar os paulistas e definir o território sob a jurisdição de um centro administrativo capaz de controlar toda a capitania. A criação da capitania se alinhava contudo, aos novos descobertos auríferos na região do atual Estado de Minas Gerais e, posteriormente, em Mato Grosso e Goiás6.

As três primeiras vilas criadas, no que seria atualmente o Estado de Minas Gerais7, foram Nossa Senhora do Ribeirão do Carmo (atual Mariana), Vila Rica (Ouro Preto) e Vila Real do Sabará, todas em 1711. Ainda seria criada em 1713, a vila de São João del Rei e no ano seguinte Vila Nova da Rainha e Vila do Príncipe (atuais Caeté e Serro). Poucas vilas seriam criadas no território mineiro até 1730 (Fonseca, 2011, p. 33).

A dificuldade na administração de um imenso território 8 obrigou a Coroa a desmembra-lo, criando a Capitania de Minas Gerais em 1720. Pela Provisão Régia de 9 de maio de 1748, os territórios ao sul, bem como os de Mato Grosso e Goiás seriam desanexados da Capitania de São Paulo e a própria capitania perderia sua autonomia, estando subordinada ao governo do Rio de Janeiro. Destacamos nesse momento a criação das primeiras circunscrições eclesiásticas, com o Bispado de São Paulo e o Bispado de Minas, ambos em 1745 (Figura 1). Criados por D. Joao V, com permissão do papa, o Bispado de São Paulo tinha sede na cidade de mesmo nome e, o de Minas, em Mariana. Seus limites confrontavam pelo Rio Sapucaí mineiro e eram, juntos, as duas circunscrições sobre toda a região que confrontava ao norte com o Bispado de Pernambuco, que se tornariam

\footnotetext{
${ }^{6}$ As minas de ouro em Mato Grosso foram descobertas em 1719, e em Goiás em 1725, fruto das incursões de Bartolomeu Bueno da Silva, o segundo Anhanguera. Sua bandeira descobriu ouro em 1725 junto ao Rio Vermelho e no Ribeirão dos Cabritos, 4 léguas da atual Goiás (Reis, 2014, p. 28)

${ }^{7}$ Devemos lembrar que nessa época a capitania de Minas Gerais ainda não existia, portanto os únicos limites definidos eram os Bispados. De acordo com Cláudia Damasceno Fonseca: “Em 1745, o papa havia concedido ao rei Dom João V permissão para instituir não apenas uma diocese em Minas Gerais - cuja sede seria fixada em Mariana - mas também três outros centros de poder eclesiástico no interior do continente: o bispado de São Paulo, bem como as prelazias de Cuiabá (Mato Grosso) e de Goiás. Conforme já foi destacado por outros autores, o objetivo dessas instituições não era somente melhorar a administração eclesiástica da colônia: elas se relacionam também a interesses de natureza geopolítica" (Fonseca, 2011, p. 119).

${ }^{8}$ A capitania de São Paulo e Minas do Ouro era a maior da colônia, compreendendo territórios do Centro-Oeste, ao sul e do sudeste, excluindo o Rio de Janeiro e a vila de Santos. Sobre o assunto ver Derntl, 2010, p. 55.
} 
regiões de litígio9. Com a criação dos novos Bispados, a capitania de Minas Gerais passava a ter ambos os governos: civil e eclesiástico, separados de São Paulo. A perda de territórios por São Paulo culminaria, como mencionamos anteriormente, na perda de sua autonomia, em 1748.

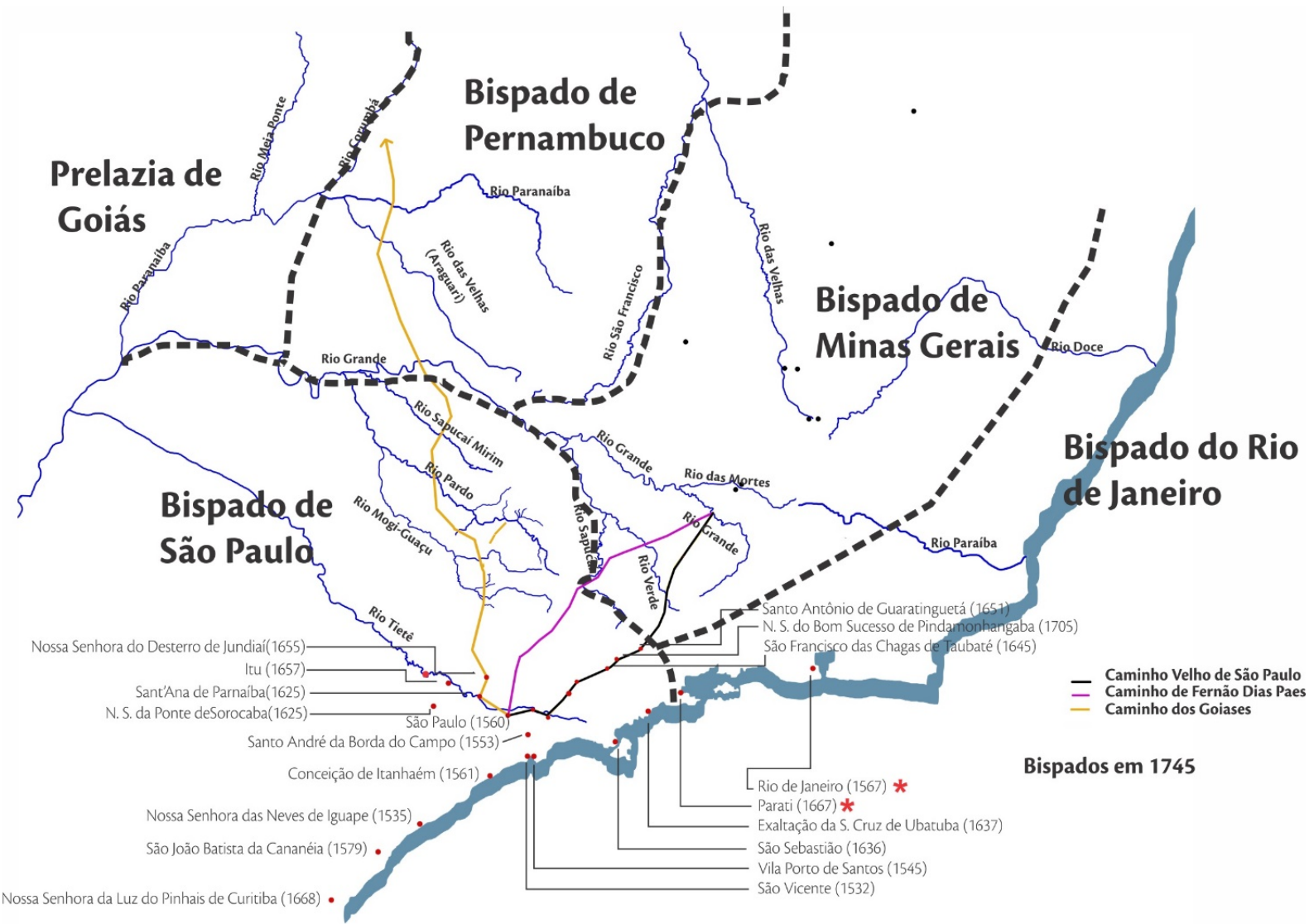

Figura 1. Mapa demonstrando a divisão entre os bispados de São Paulo e Minas Gerais, criados em 1745, em relação ao Bispado de Pernambuco. No mapa estão destacados os antigos caminhos em direção às regiões das minas: em preto o Caminho Velho para São Paulo; em roxo o caminho da bandeira de Fernão Dias Paes; em amarelo o caminho dos Goiases ou "Estrada do Anhanguera", aberto no início do século XVIII. Estão ainda indicadas as vilas formadas até 1745: em vermelho as vilas paulistas (excetuando-se Rio de Janeiro e Parati, fundadas em território carioca) e em preto, as vilas mineiras. Fonte: Elaborado pelos autores sobre base digital do IBGE (2009). Recuperado de: http://mapas.ibge.gov.br/ politico-administrativo/regionais, Acesso em: 22 mar. 2017.

A restauração da capitania de São Paulo, em 1765, viria com a nomeação do governador-general D. Luiz Antônio de Souza Botelho Mourão, o de Morgado de Mateus, e dentre as suas políticas estava a criação de novas vilas e freguesias, agrupando a população antes dispersa pela capitania em sítios volantes. 0 Morgado de Mateus também se empenhou na resolução dos conflitos com os espanhóis ao sul e na definição de novas fronteiras com Minas Gerais.

De fato, a capitania de São Paulo, depois que perdeu sua autonomia, havia sobrevivido graças às rotas comerciais estabelecidas, movidas pelo tropeirismo e sustentadas por pousos ao longo dos caminhos, que acabaram por criar uma constelação de povoados que dariam origem a novas freguesias e vilas 10.

O caminho mais significativo nesse contexto foi a "Estrada dos Goyases" ou "Caminho do Anhanguera", aberto em fins do século XVII por Bartolomeu Bueno da Silva, que já entre 1673 e 1682 percorreu

\footnotetext{
${ }^{9}$ Anteriormente a 1745 os bispados se dividiam em três: Arcebispado da Bahia, Bispado de Pernambuco e do Rio de Janeiro, de onde deste último separaram-se os dois bispados de São Paulo e Minas Gerais.

10 Para Beatriz Piccolotto Siqueira Bueno, "quando extinta, a Capitania de São Paulo sobrevivera graças ao seu interrelacionamento com as regiões vizinhas, assegurado pelas "monções" e pelo tropeirismo, nas respectivas rotas do Cuiabá e do Viamão. No que tange à agricultura, embora restrita e acanhada, ela ocupava metade da população, dedicada sobretudo à lavoura de subsistência" (Bueno, 2009, p. 285).
} 
os sertões de Goiás, visando o apresamento de indígenas. A técnica de desbravar os sertões em bandeiras, guiadas por índios, produziram nos paulistas o modus operandi para iniciar o povoamento, produzindo pousos e sítios que margeavam essa importante rota11. 0 caminho partia de São Paulo, Santana de Parnaíba, seguindo para Jundiaí. De onde seguia em direção ao norte pelo rio Atibaia, Jaguari, Mogi, Pardo e Grande, cruzando a atual fronteira com o Estado de Minas Gerais. Vários pousos e sítios, alguns devido ao seu constante crescimento, foram elevados à freguesia e depois à vila, como no caso do pouso de Campinas do Mato Grosso, mais tarde freguesia de Nossa Senhora da Conceição das Campinas do Mato Grosso (1774, no termo da vila de Jundiaí), depois vila de São Carlos (1797), atual município de Campinas.

A bandeira liderada por Fernão Dias Pais (assinalada no mapa da figura 1), partiu de São Paulo em 1674, permanecendo em Minas até a morte de seu comandante. Responsável por fundar núcleos na região do rio das Velhas, a bandeira também teve como objetivo o apresamento indígena, os quais eram enviados em quantidade até São Paulo desde 1600 (Fonseca, 2011, p. 61-62). Outras redes de caminhos foram abertos, a partir da segunda metade do século XVIII (Figura 2), conectando as rotas paulistas à região dos novos achados auríferos nas regiões limítrofes com Minas Gerais, tema que iremos aprofundar em tópico a seguir.

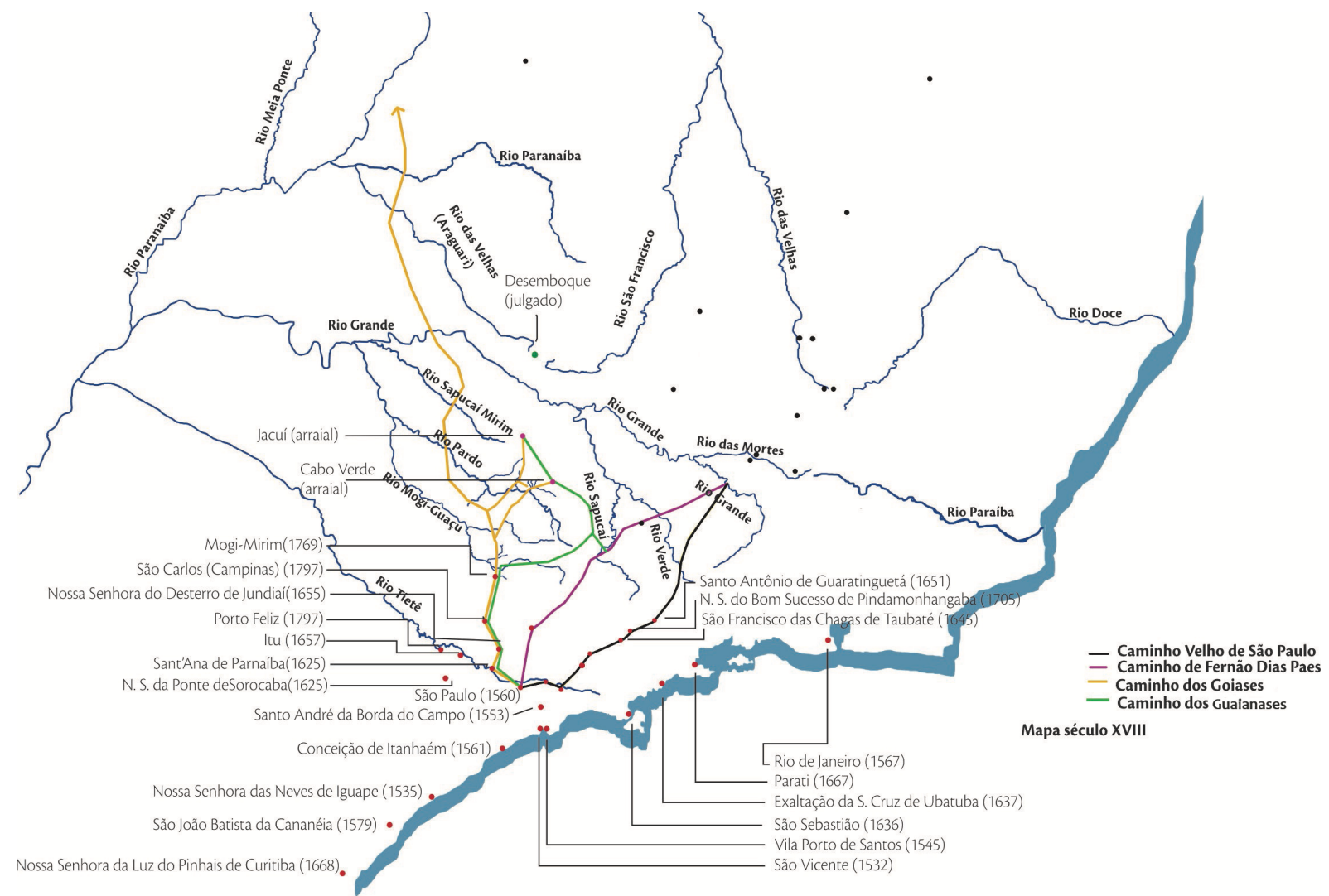

Figura 2. Mapa demonstrando a rede urbana em formação, em fins do século XVIII. Estão destacadas em vermelho as vilas fundadas no território paulista e, em preto, as fundadas no território mineiro. Os dois pontos destacados em roxo, referem-se aos arraiais de Jacuí e Cabo Verde. Percebe-se o aumento da rede de caminhos e trilhas, abertos em decorrência do caminho do Anhanguera, em amarelo: o caminho dos "Guaianases", em verde, aberto na segunda metade do século XVIII conectava importantes regiões onde situavam-se achados auríferos (atuais municípios mineiros de Jacuí e Cabo Verde). 0 caminho conectava-se ao Caminho de Fernão Dias Pais, na altura de Santana do Sapucaí (atual município mineiro de São Sebastião da Bela Vista). A vila mais nova a ser fundada é São Jozé de Mogimirim (1769) pelo Morgado de Mateus, enquanto que a rede urbana em Minas se expande em sentido oeste. Fonte: Elaborado pelos autores sobre base digital do IBGE (2009). Recuperado de: http://mapas.ibge.gov.br/politico-administrativo/regionais

Acesso em: 22 mar. 2017.

\footnotetext{
11 Sobre esse tema, consultar a obra de Nestor Goulart Reis: “O Caminho do Anhanguera” (2014). Segundo o autor, a bandeira de Bartolomeu Bueno as Silva, descobrindo ouro na região de Goiás, foi responsável pela fundação que seria elevado à condição de vila em 1739, com o nome Vila Boa de Goiás. A descoberta das minas lhe rendendo os direitos de passagem pelos rios Atibaia, Jaguari, Pardo, Grande, das Velhas, Paraná, Corumbá, Meia Ponte e Claro (Reis, 2014).
} 
Os mapas das Figuras 1 e 2 demostram a densidade de ocupação, até fins do século XVIII, pela rede urbana mineira e paulista. 0 ritmo da criação de vilas em território mineiro, bastante acentuado no início do século XVIII, decai significativamente por volta de 1730 . De fato, a elevação de vilas em Minas Gerais passaria por um período de estagnação; no governo de Gomes Freire de Andrade (1735-1763) nenhuma vila havia sido fundada e a sistemática permaneceria até fins da década de 1780 (Fonseca, 2011).

O governo paulista, no entanto, vinha conquistando territórios, durante o século XVIII, em função de expedições que encontraram ouro nos limites com a capitania de Minas. A última vila criada com jurisdição sobre o "Sertão do Rio Grande" fora Jundiaí, em 1655, e todo o território, compreendido entre os rios Mogi-Guaçu e Grande, pertenciam à freguesia de Mogi-Guaçu, criada em 1740 , pertencente a então à vila de Jundiaí. Os novos achados auríferos na região do Rio Grande e a necessidade de assegurar a sua posse iriam levar à criação da Vila de "São Jozé de Mogimirim", em 1769, como estratégia do Governador de São Paulo, Morgado de Mateus, de consolidação da posse paulista sobre os territórios.

\section{A conquista do território, circunscrição civil e eclesiástica: o papel estratégico da freguesia de Nossa Senhora da Conceição do Bom Sucesso do Rio Pardo.}

O conflito acerca das divisas de fronteira entre Minas e São Paulo foi publicado, em 1896, como parte da série "Documentos Interessantes para a História e Costumes de São Paulo"12, cujo volume XI é dedicado inteiramente ao assunto. 0 volume foi organizado por Orville Derby, que redigiu o prefácio e a longa introdução que esclarece e resume os conflitos de divisa entre as duas capitanias, iniciados no século XVIII.

A elevação à vila da freguesia de São Jozé de Mogimirim ${ }^{13}$, em 22 de outubro de 1769, pelo Morgado de Mateus, delimita um termo que teria como limite ao norte o rio Grande, passando dessa forma, todo esse sertão a estar sob a jurisdição dessa vila. A ação empreendida por D. Luiz Antônio de Souza Botelho Mourão, refletia os interesses da política pombalina de urbanização, pela fixação de uma população antes dispersa pelo território. No auto de elevação à vila de São Jozé de Mogimirim, em correspondência de 27 de junho de 1769, o Morgado de Mateus escreve:

[...] que era muito convincente ao seu Real Serviço que nessa Capitania se erigissem Villas naquelas partes onde fossem mais convenientes e que a ellas se congregassem todos os vadios e dispersos que vivessem em sítios volantes para morarem em povoações civis, em que se lhes pudessem administrar os sacramentos e estivessem promptos para as occaziões do seu Real Serviço14 (AESP, 1896, pp. 173-174).

A jurisdição estabelecida, evidenciando a conquista do sertão, articulava os interesses reais com a necessidade de restauração da autonomia política da capitania de São Paulo, subordinada à capitania do Rio de Janeiro desde 1748. De acordo com Beatriz Piccolotto Siqueira Bueno, [...]

[...] a política de Pombal enquadrava a capitania na engrenagem do todo, mas, pela primeira vez, esboçava uma preocupação com o desenvolvimento do seu próprio território. [...] A capitania era agora, pela primeira vez, objeto de um programa que a beneficiava (Bueno, 2009, p. 285).

A divisão entre a nova vila de São José de Mogimirim, criada em 22 de outubro de 1769, e a vila de Nossa Senhora do Desterro de Jundiahy foi dada por certidão, de 14 de outubro de 1769, a qual define "que o termo desta seria até o barranco do Rio Jaguary, onde se fincaria o marco, e delle para adiante seria o termo da Villa nova de s. Jozé de Mogimirim até o Rio Grande do caminho de Goyases" (AESP,

\footnotetext{
12 A coleção intitulada Documentos Interessantes para a História e Costumes de São Paulo foi criada por Toledo Piza, fundador do Arquivo do Estado de São Paulo, em 1894. Foram transcritos documentos sob a guarda do Arquivo, bem como de particulares, e reunidos em 95 volumes, atualmente em suporte digital pela UNESP.
}

${ }^{13}$ Atual município de Mogi Mirim, em São Paulo.
${ }^{14}$ A grafia antiga foi mantida em todas as transcrições dos Documentos Interessantes, da AESP (1896).

(C) Labor \& Engenho, Campinas [SP] Brasil, v.11, n.3, p.313-334, jul./set. 2017. 
1896, p. 180). 0 rio a que se refere a certidão de 1769, é o Jaguari, que nascendo na serra da Mantiqueira, deságua no Rio Atibaia, divisa do atual município de Campinas (SP), e que não deve ser confundido com o Rio Jaguary Mirim, mais ao norte.

A elevação da vila de Mogi-Mirim revela, da mesma forma, a política de controle por parte da capitania de São Paulo restaurada, sobre os achados auríferos, em regiões de litígio com a capitania de Minas Gerais. Nos referimos especificamente ao caso da região de Caconde, município paulista localizado na atual divisa dos Estados de São Paulo e Minas, que teve sua ocupação iniciada com os achados auríferos na década de 1750, na região dos rios Bom Sucesso e São Mateus.

A segunda freguesia criada dentro do termo da vila de Mogi-Mirim, depois da freguesia de Mogi Guaçu foi Nossa Senhora da Conceição do Bom Sucesso do Rio Pardo (atual município de Caconde), cujo termo definiria toda a jurisdição sobre o território até o Rio Grande. Identificamos, sobre base cartográfica de 1879 da Província de São Paulo, o que seriam as divisas do termo da vila de MogiMirim, bem como a freguesia de N. S. da Conceição do Bom Sucesso do Rio Pardo (Figura 3). A denominação da freguesia guarda em si a localização dos achados auríferos na região: na barra do rio Bom Sucesso, tributário do Rio Pardo.

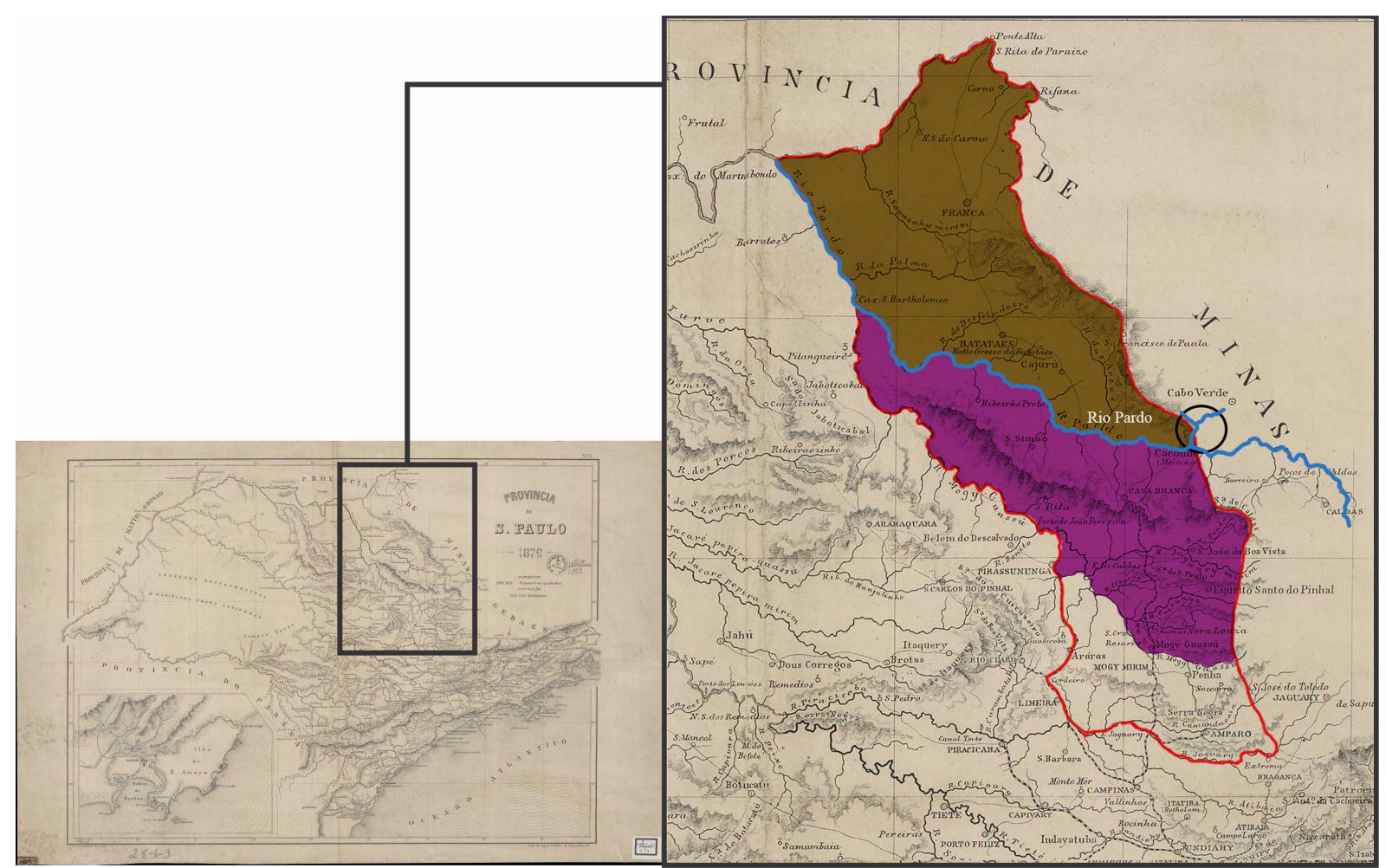

Figura 3. Interpretação acerca dos limites da freguesia de Nossa Senhora da Conceição do Bom Sucesso do Rio Pardo (atual município de Caconde), elevada em 1775, destacada na cor marrom, bem como a freguesia de Mogi Guaçu, criada em 1740, destacada no mapa na cor roxa. Em vermelho, o termo da vila de Mogi-Mirim. O Rio Pardo e seu afluente na região de Caconde, o Rio Bom Sucesso, estão destacados no mapa. O Rio Pardo nasce no atual município mineiro de Ipiúna, passando na região de Caldas, como demostrado no mapa. Fonte: Biblioteca Nacional. Recuperado de: http://objdigital.bn.br/objdigital2/acervo_digital/div_cartografia/cart168295/cart168295.html — Acesso em: 22 mar. 2016. Elaborado pelos autores sobre Mapa da Província de São Paulo, de Claudio Lomellino de Carvalho, 1879.

A nova freguesia de Nossa Senhora da Conceição do Bom Sucesso do Rio Pardo, passou a ocupar parte do território que compunha a freguesia de Mogi Guaçu, limitando-se ao sul com o Rio Pardo. A divisão havia sido dada em 1775, por Dom Frei Manoel da Ressureição, Bispo de São Paulo, para a nova freguesia de Nossa Senhora da Conceição do Bom Sucesso do Rio Pardo:

[...] do Rio Grande até o Rio Pardo correndo pelas estrada de Goiás, e suas povoações, partindo com as da freguesia de Jacuí, e no Rio Pardo entestando com a freguesia de Mogi-Guaçu, sobre a divisa e demarcação desta freguesia da dita passagem do Rio Pardo estrada de Goiás pelo rio acima até as suas cabeceiras e depois correrá rumo direto até o 
rio Jaguari-Mirim, ficando todo este dito sertão até o Registro ${ }^{15}$ de São Mateus que confina com os fregueses de Cabo Verde para a Freguesia deste Rio Pardo (Campanhole, 1979, p. 168).

A divisa oriental da freguesia estava no Registro de São Mateus, que confinava com os fregueses de Cabo Verde (atual Cabo Verde, MG), em uma região denominada na documentação da época como "Cabeceiras do Rio Pardo", onde encontrava-se a sede da freguesia de Nossa Senhora da Conceição. Na introdução do volume XI dos Documentos Interessantes para a História de São Paulo, Orville Derby aponta para os descobertos auríferos na região de Caconde (antiga freguesia de Nossa Senhora da Conceição do Bom Sucesso do Rio Pardo), limítrofe com as Minas Gerais.

Achavam-se situadas nos valles de diversos tributários que para o Rio Pardo descem do espigão entre Jacuhy e Cabo Verde, no distrito que desde aquele tempo tem conservado o nome de Caconde (AESP, 1896, p. 29).

Nessa região havia aumentado o número de caminhos e trilhas abertos em função dos novos descobertos auríferos, mas também da comunicação entre as duas capitanias. No ano de 1765, quando o Morgado de Mateus assume como governador da recém restaurada Capitania de São Paulo, as principais vias de comunicação eram as estradas de Goiás, pelo lado paulista, e em Minas, as picadas abertas por Dom Luiz Diogo, governador dessa capitania. A região de Caconde, freguesia paulista no termo de Mogi-Mirim, estava nos interstícios entre as duas rotas, e sua posição, foi fundamental para assegurar a posse paulista da região (Figura 4). Nos Documentos Interessantes, Orville Derby esclarece a rede:

Na ocasião de se estabelecer o convênio havia nas quase desertas regiões limítrofes das duas Capitanias duas estradas que limitavam uma zona larga inabitada, porém destinada infalivelmente a se tornar povoada e cortada por novas estradas transversais. Eram estas a Estrada de Goyas pelo lado paulista e, pelo lado mineiro, as antigas picadas, abertas de novo por Luiz Diogo, do Desenboque por Jacuhy, Cabo Verde, Campestre, Ouro Fino e Comandocaia pra Santa Anna do Sapucahy. Ligando estas duas estradas através da zona despovoada havia as duas estradas transversais de Comamdocaia a Atibaia e São Paulo e de Jacuhy à estrada de Goyas no registro paulista de Itupeva, adiante de Mogyguassú (AESP, 1896, p. 63).

0 primeiro descoberto aurífero ao sul do Rio Grande, no chamado Sertão do Rio Grande da vila de Jundiaí, deu-se em 1755, por Pedro Franco Quaresma16. Sua posse deu-se em 7 de outubro do mesmo ano, na paragem denominada Borda do Mato, atual região de Mococa, margem do Ribeirão das Canoas17. Segundo o pesquisador Adriano Campanhole, "por esses sertões penetrara também Veríssimo João de Carvalho, descobridor e fundador de Cabo Verde (1762).

\footnotetext{
15 Os registros foram, no período colonial, paragens construídos como entreposto de passagem, onde eram fiscalizados os viajantes. Notadamente em áreas de mineração era cobrado o quinto, imposto correspondente à quinta parte de todo o ouro que circulava nas capitanias. A guarda do registro era determinada à uma tropa de Ordenanças, e seu chefe local, o Comandante do Registro.

16 Pedro Franco Quaresma, sertanista que primeiro encontrou ouro na região do Rio Grande, era, segundo nos esclarece Adriano Campanhole (1979), juiz ordinário da vila de Jundiaí, sendo nomeado em 2 de janeiro de 1763 (Campanhole, 1979, p. 54). Em 1763 havia tomado posse do "Novo Descoberto de Nossa Senhora da Conceição do Ribeirão de São Pedro de Alcântara e Almas" (Campanhole, 1979, p. 54), localidade chamada ainda de Arraial de São Pedro e Almas do Emboque, atual Jacuí [MG]. Estavam os paulistas portanto na jurisdição da vila de Jundiaí, no entanto, em território mineiro pela antiga demarcação do ouvidor Thomaz Rubi, em 1749.

17 Os Documentos Interessantes, assinalam o auto de posse do Sertão do Rio São João (Jacuhy): “do Rio de São João que faz barra no dito Rio Grande, e por ele acima até onde finalizar o dito Pedro Franco com a sua deligência, e tão bem de todo o Certão além do dito Rio S. João até o Rio de Sapucahy das Campanhas de Itajubá, e por ele acima até onde se reparte o distrito das mesmas Campanhas" (AESP, 1896,p. 63).
} 


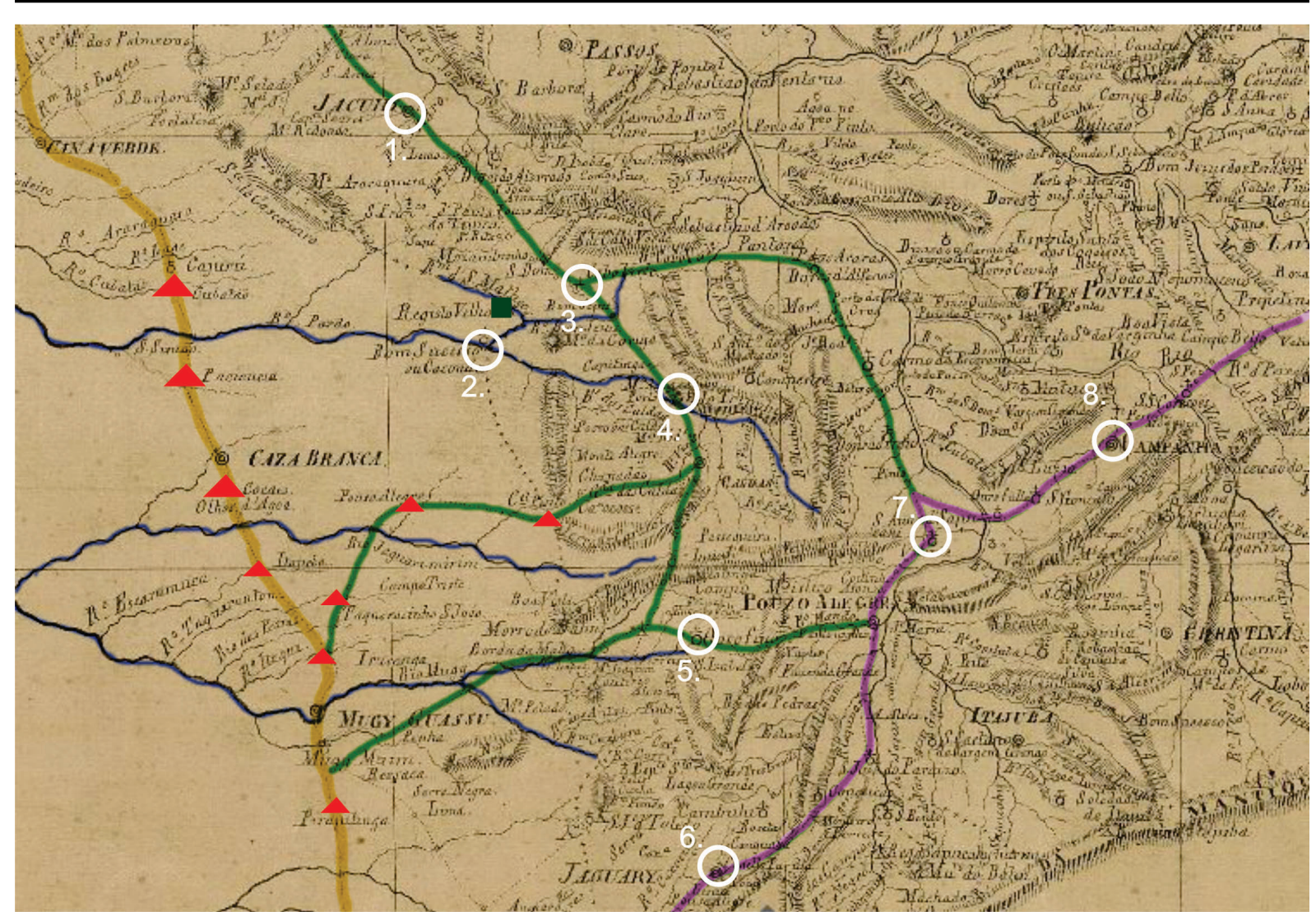

Figura 4. Recorte sobre o mapa "Carta chorographica da provincia de Minas Gerais" de 1863, de autoria de Frederico Wagner. Nele e possível identificar a rede formada pelo Caminhos dos Goiases (em cor alaranjada), destacando as fazendas formadas nesse trajeto a partir dos pousos (destacados pelos triângulos vermelhos) ainda no século XVIII. Em verde destacamos a rede de caminhos abertos em Minas Gerais, mencionados nos Documentos Interessantes, da APESP, v.11. A rede interligava o arraial de Jacuí (número 1), seguindo para Cabo Verde (número 3), a freguesia de Caconde (número 2) é marcada juntamente com o registro de São Matheus (quadrado verde). Desse ponto o caminho poderia seguir para Campestre (número 4), Ouro Fino (número 5), Camanducaia (número 6), interligando com o caminho de Fernão Dias até Santana do Sapucaí (número 7) e Campanha (número 8). A hidrografia foi destacada em azul. Fonte: Elaboração dos autores sobre original, Biblioteca Nacional. Recuperado de: http://objdigital.bn.br/acervo_digital/ div_cartografia/cart309977/cart309977.htm — Acesso em 23 mar. 2017.

Todo o território era considerado paulista, com posse civil e eclesiástica (Cabo Verde somente no eclesiástico) ${ }^{18}$ (Campanhole, 1979, p. 55). Havia, como mencionamos pela documentação citada, a sobreposição das jurisdições entre o Bispado de São Paulo, que declarava ser sua a posse de todo o Sertão do Rio Grande, e as divisões de fronteira feitas anteriormente pelo governador mineiro Dom Luiz Diogo Lobo da Silva, e efetuadas por Thomaz Ruby ${ }^{19}$. A confirmação ou não da posse de tais

18 0 território de São Paulo estendia sua jurisdição aos sertões por meio da rede de vilas e freguesias e pelos limites do Bispado de São Paulo (posse eclesiástica) que estendia-se até o Rio Sapucaí mineiro. Devemos lembrar no entanto, que Estado e Igreja estavam unidos, e que fundar cidades significava aplicar uma sistemática religiosa, de acordo com as Constituições Primeiras do Arcebispado da Bahia. No entanto havia diferenças fundamentais entre a fundação de freguesias e vilas por paulistas, que estariam subordinadas ao Governo da Capitania de São Paulo, e da jurisdição do Bispado de São Paulo que estendia-se sobre povoações dentro dos limites do Governo da Capitania de Minas Gerais. Dessa forma, a região dos novos descobertos estaria sob a jurisdição do Bispado de São Paulo, incluindo Cabo Verde, que era freguesia paulista, porém dentro do território da Capitania de Minas Gerais. A sobreposição dessas duas redes de natureza diferente foi comum e, como veremos adiante, foi o cerne dos conflitos na fronteira entre São Paulo e Minas Gerais.

${ }^{19}$ A Provisão Régia de 9 de maio de 1748, que determinava a supressão da Capitania de São Paulo, entre outras coisas, instituía ao Governador Gomes Freire de Andrade, encarregado provisoriamente do governo das três capitanias (São Paulo, Minas e Rio de Janeiro) de traçar a divisa entre Minas e São Paulo "pelo Rio Grande e pelo Rio Sapucahy ou por onde vos parecer" (AESP, 1896, p. 155). A demarcação que deveria ser a solução do problema das divisas torna-se mais complicada quando Gomes Freire imagina outra divisa, pelo cume das serras da Mantiqueira e Mogi-Guaçu, que equivocadamente acreditava-se formarem um único espigão. Para tanto, encarrega o Ouvidor da Comarca do Rio das Mortes, Thomaz Rubim de Barros Barreto de realizar a demarcação em 1749, que por sua vez cria uma nova linha dos limites, que deveria seguir "até chegar ao Rio Grande acompanhando por uma lado a estrada que vai de São Paulo para Goyases" (AESP, 1896, p. 159), tornando assim a linha divisória passível das mais variáveis interpretações. 
territórios dava-se pelo processo de ocupação e manutenção de uma estrutura militar na região, ligada à existência dos registros, sacramentados nos atos de posses pelos governadores das duas Capitanias. 0 Conselho da vila de Jundiaí tomou posse, em 7 de outubro de 1755, do "sertão do Rio São João20 (Jacuí) e, em 24 de setembro de 1761, o bispado de São Paulo toma nova posse, do então nomeado "Descoberto do Desemboque",21 registrando como justificativa o fato da jurisdição do bispado de São Paulo ter como limite o Rio Grande22.

O governo de Minas iria realizar mais uma investida contra a Capitania de São Paulo quando, em 26 de novembro de 1764, D. Luiz Diogo, governador de Minas, toma posse dos descobertos em expedição que tinha por finalidade abrir um caminho ligando as novas faisqueiras à São João del Rei, onde se encontrava a Casa de Fundição. Menciona ainda a extinção dos quilombos e a guarda dos caminhos para que não houvessem extravios de ouro. Dessa forma, o governador de Minas continua sua investida no território paulista, quando, em 1764, cria o julgado 23 de Jacuí, incluindo nessa jurisdição, o Descoberto do Desemboque (Fonseca, 2011).

Esse evento merece destaque dentro da história da formação territorial na região de fronteira: as ações proferidas por D. Luiz Diogo iriam repercutir por muito tempo, como mencionado no "Sumário" de Vellozo e Gama (AESP, 1896, p. 378).

O Sumário foi lavrado em nove de maio de 1780, na vila de Mogi-Mirim, pelo Desembargador Miguel Marcellino Velloso e Gama, para realizar uma averiguação da situação das divisas entre as Capitanias de São Paulo e Minas Gerais, por ordem do então Governador Bernardo José de Lorena. 0 documento tinha o objetivo de averiguar as alterações de divisa deixadas após a saída do último governador de São Paulo, Francisco da Cunha e Menezes.

Entre as testemunhas que relataram ao Desembargador sobre as divisas entre as capitanias, a resposta foi unânime: havia sido feita pelo Rio Sapucaí, estando os arraiais de Jacuí, Cabo Verde e Ouro Fino em território paulista. Fica claro que a divisão pelo Sapucaí se refere aos limites dos dois Bispados, e que as testemunhas os tomavam como limites das capitanias, em situação que favorecia o governo de São Paulo. Relatam ainda que

Os Descobrimentos de Jacuhy por Pedro Franco Quaresma, Cabo Verde, Santa Anna de Sapucahy e Ouro Fino por Verissimo João de Carvalho forão uzurpados todos estes descubrimentos a esta Capitania de São Paulo pello Govemo de Minas Gerais com forsa militar (AESP, 1896, p. 382).

Foi nesse ato que se deu a posse, por parte de Minas Gerais, do arraial de Cabo Verde, que havia sido instituído pelo Bispado de São Paulo, e constava nos limites deste:

[...] o General Luis Diogo Lobo da Silva se meteu também de posse do Arraial de Cabo Verde deitando fora o Vigario que se achava posto pello Bispado de Sam Paulo deixando outro digo deixando no Padre Agostinho Machado de Vasconsellos em Lugar do vigario Joaquim Pedroso de Almeyda a quem violentamente tirarão as chaves da Igreja para o entregar ao sobredito Padre Agostinho Machado Vasconsellos (AESP, 1896, p. 383).

O conflito acerca da posse sobre os novos locais de mineração tomou novos rumos com a política do Morgado de Mateus, destacada anteriormente. A solução apontada pelo novo governador, aplicador

20 Documentos Interessantes (AESP, 1896, p. 63).

21 Documentos Interessantes (AESP, 1896, p. 66).

220 bispado de São Paulo havia sido criado por D. João V, em 22 de abril de 1745, assim como o bispado de Mariana.

23 Segundo Cláudia Damasceno Fonseca, "os julgados eram os territórios de jurisdição de um juiz ordinário - ou seja, de um juiz 'leigo' (sem o título de bacharel) de primeira instância. [...] diferentemente dos concelhos, os julgados era circunscrições com autonomia judiciária parcial - ou seja, sem jurisdição completa (cível, crime, administração de bens dos órfãos) - e sem autonomia administrativa, o que os tornava independentes de um concelho vizinho, em um ou mais aspectos" (Fonseca, 2011, p. 189). A criação dos julgados em locais como a povoação de Jacuí, constituía-se de uma medida do governo para adotar jurisdições onde não fosse desejado ou possível erigir vilas (Fonseca, 2011). 
da política do Marquês de Pombal, foi a de mandar impedir os descobertos em 10 de fevereiro de 1766 , ordenando o governador que fossem colocadas duas guardas nos ditos descobertos, impedindo o acesso de paulistas e mineiros, bem como a extração de ouro.

Conflitos de litígio envolvendo a região de Caconde ocorreram também em relação às circunscrições eclesiásticas mineiras - a freguesia de Cabo Verde - que tentou em várias ocasiões tomar para si a jurisdição da freguesia de Caconde. Uma via de comunicação havida sido aberta, em 1760 por Veríssimo João de Carvalho, ligando os caminhos de Ouro Fino a Cabo Verde, e de lá até Jacuí e o Desemboque. Outra picada foi aberta ligando a freguesia de Mogi-Guaçu ao registro de São Mateus, conhecida como Picada de São Matheus (Bacellar \& Brioschi, 1999, p. 40). Esses caminhos foram ramificações dos traçados iniciais, da estrada do Anhanguera e as trilhas mineiras, apontadas no mapa anterior (Figura 4).

Nos Documentos Interessante, volume XI, podemos ter uma ideia dos conflitos envolvendo os caminhos e registros. Em carta de 6 de março de 1777, diretamente ao Rei D. João VI, queixam-se os mineiros de Cabo Verde sobre a posse dos locais de mineração no Ribeirão Bom Sucesso, alegando terem sido obrigado pelo Comandante da Guarda Paulista na região (Registro de São Matheus) a pagarem o quinto à capitania de São Paulo. Na carta ainda relatam:

[...] serem as ditas terras descobertas pelos moradores desta Freguezia (Cabo Verde), e serem concedidas antes, que o IlImo. e Exmo. Senhor General mandasse guarda para outro Ribeirão distante mais de duas legoas, donde se tem vindo alargando por esta Capitania (AESP, 1896, p. 318, grifo nosso).

Na "Carta do Comandante do Registro no Rio Pardo, em 16 de agosto 1775" endereçada ao governador de São Paulo, Capitão General Martin Lopes Lobo de Saldanha, o referido comandante queixa-se do vigário da freguesia de Cabo Verde, que tendo falecido um mineiro no descoberto do Rio Pardo, "freguês desta freguesia", o corpo do mesmo foi levado à força pelo vigário do arraial mineiro, acompanhado de um bando armado, e ainda completa:

[...] agora novamente diz o Padre Vigário do dito Arrayal de Cabo Verde, que tem ordem do Illmo. Cabido de Minas para vir a este descoberto prender o Rvdo. Vigário, e botar abaixo a igreja (AESP, 1896, pp. 314-315).

O comandante na ocasião, Jeronimo Dias Ribeiro ${ }^{24}$, havia recebido ordens do Capitão General de São Paulo para não deixar passar "pessoa alguma de qualquer localidade", por carta assinada em 6 de julho de 1775, pouco tempo antes do ocorrido com o vigário de Cabo Verde.

Outras correspondências, do ano de 1777, ilustram a tentativa de Minas Gerais em cobrar impostos sobre o ouro extraído na região do Registro do Rio Pardo, enviadas por Martin Lopes Lobo de Saldanha, governador de São Paulo, ao comandante do Registro, Jerônimo Dias Ribeiro:

[...] fez Vm. Muito bem em a não deixar executar, porque os moradores do continente de São Paulo nenhuma obrigação tem de contribuir para a derrama a que estão obrigados os de Minas: em cujos termo observe Vm. Inviolavelmente as ordens, que tem do meu Predecessor o Exmo. Snr. D. Luiz Antônio de Souza, que eu por estas lhas retefico, e lhe as dou por muito recomendadas" (AESP, 1896, p. 317).

A intenção do governo mineiro era a de repartir datas minerais em território paulista, o que fica evidente pela resposta ao governador de São Paulo, enviada por Jerônimo Dias Ribeiro, em carta

\footnotetext{
${ }^{24}$ Natural de Mogi-Guaçu, onde casou-se em 1768, Jeronimo Dias Ribeiro recebe a patente de sargento em 10/10/1758. Foi ainda nomeado para a tropa de Santos, em 29/03/1774, bem como para a Companhia de Ordenanças de Santo Amaro, em 15/10/1788 (Campanhole, 1979, p. 139). Foi Comandante responsável pela Guarda do Rio Pardo, em 1772, onde depois de suas nomeações retornou a esse posto, tendo comandado o Registro do Rio Pardo, em São Matheus, até o dia em que foi retirado, por volta de 1807, por motivos de sua velhice. Aparece em várias cartas e documentos como sendo o responsável pela guarda e registro do ouro na freguesia de Caconde, sendo sua função fundamental para assegurar a posse do dito local.
} 
do mesmo25. Os conflitos, no entanto, iriam se manifestar por parte de Minas Gerais, relativos aos caminhos e picadas abertos para a comunicação entre os arraiais mineiros (Figura 5). Em carta endereçada ao governador de Minas, em 11 de dezembro de 1777, o Comandante da Guarda de Jacuhy (arraial mineiro localizado ao norte de Caconde) queixa-se:

Deste destricto de Jacuhy para a Capitania de São Paulo há uma estrada aberta desde o tempo que está descoberto este mesmo destricto ( que segundo dizem há 16 anos) pela mesma giram os comerciantes deste Arrayal para a dita Capitania sem terem outra mais cômoda, pelo que se faz preciso dar parte a V. Exmo. em como agora proximamente houve pessoa que foi enganar o Illmo. e Exmo. Senhor General de São Paulo, e o mesmo senhor mal informado mandou tapar a referida estrada, ordenando se siga por outra que vay sahir a paragem chama Quaconda perto do Arrayal de Cabo Verde, e nestes termos não pode girar o negociante para este Arrayal, por ficar aquele caminho com grande volta, $e$ trabalhoso, e só está bem cômodo para extraviar ouro desta Capitania para aquela. (AESP, 1896, p. 319, grifo nosso).

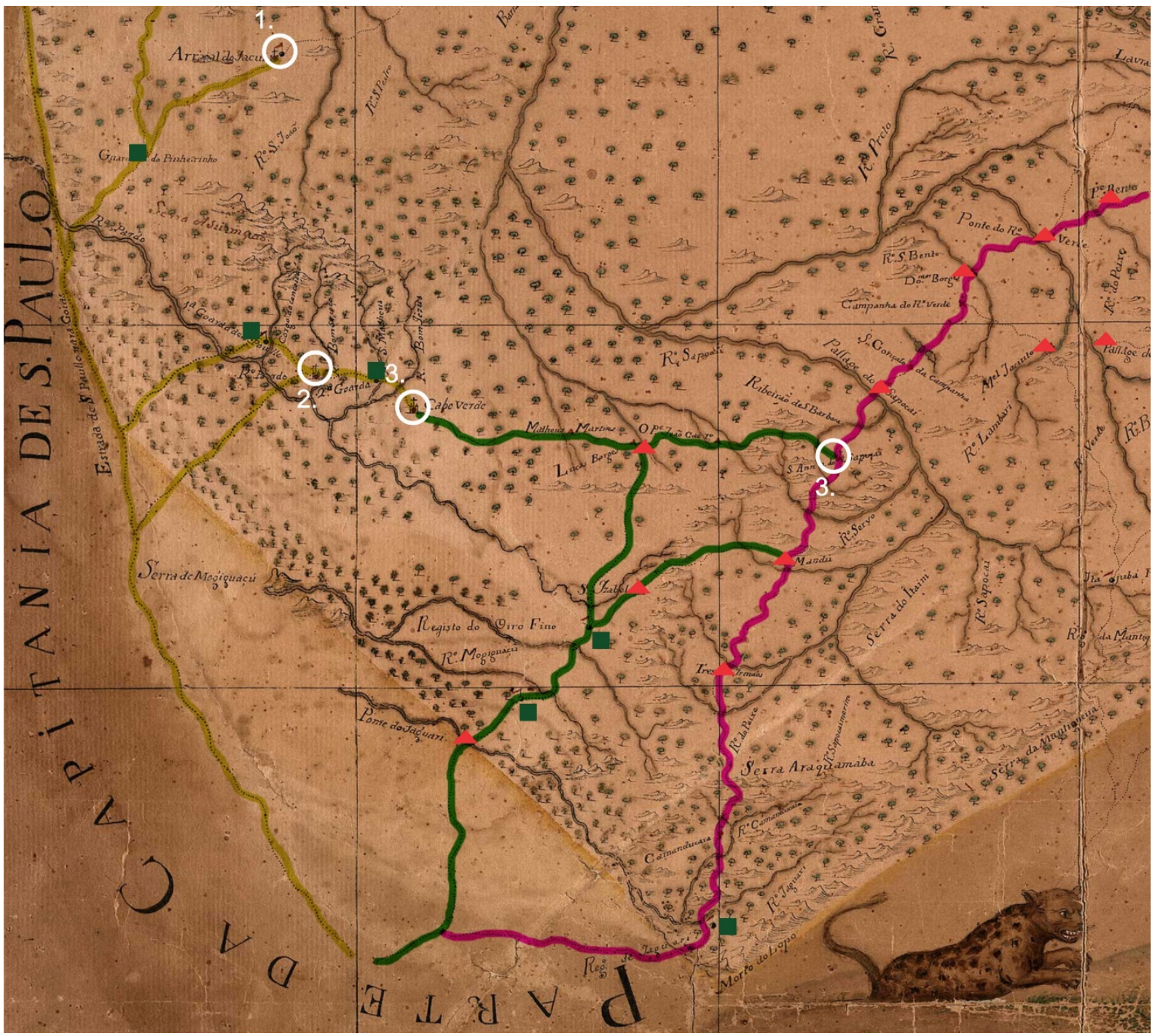

Figura 5. Recorte sobre o "Mappa da Comarca do Rio das Mortes, pertencente a Capitania das Minas Gerais", de autoria de José Joaquim da Rocha, em 1777. Nele destacamos em amarelo o caminho dos Goiases, em verde o caminho dos Guaianases e, em roxo, o antigo caminho de Fernão Dias Pais. As transversais originaram-se nesses caminhos, interligando a capitania de Minas Gerais à capitania de São Paulo. Nessa rede de caminhos foram colocados registros

25 Sobre esse assunto, Cláudia Damasceno Fonseca comenta: “O objetivo era claro: ao incorporar novas terras ao território de Minas, ampliava-se o 'círculo dos contribuintes', o que podia ajudar a evitar as derramas, tão temidas pela população. [...] Além disso, a exploração econômica das regiões anexas iria, sem dúvida, fazer com que aumentassem as receitas da capitania (Fonseca, 2011, pp. 198,199). Os conflitos na região de Caconde, com as tentativas de anexação do território por parte da freguesia de Cabo Verde ilustram as observações da autora. 
(destacamentos de soldados), identificados no mapa pelos quadrados verdes, assim como as fazendas, destacadas pelos triângulos vermelhos. As freguesias foram marcadas pelos círculos em branco, cujo no 1 corresponde à freguesia de Jacuí, o no 2 à freguesia de Caconde e o no 3 à freguesia de Cabo Verde e o no 4 à freguesia de Santana do Sapucaí. Fonte: Elaborado pelos autores sobre original, Biblioteca Nacional. Recuperado de: http://objdigital.bn.br/acervo_digital/ div_cartografia/cart530294/cart530294.html — Acesso em 23 abr. 2017.

Em outra correspondência do Comandante Jerônimo Dias Ribeiro, em 21 de setembro de 1778, o governador de São Paulo reitera a afirmação do referido comandante em correspondência anterior onde relatava a terem cessado as "inquietações que os habitantes de Minas Gerais faziam a esse Registro" (AESP, 1896, p. 321), ordenando ainda o fechamento de todos os caminhos comunicantes com a Capitania de Minas.

O primeiro registro estabelecido na região foi onde hoje encontra-se o município de Mococa, e ficou conhecido pelo nome de Borda do Mato, nas margens do Ribeirão das Canoas, que ainda conserva o mesmo nome. Teria sido esse registro proveniente de Itupeva (atual região do município de Aguaí, nas proximidades do antigo caminho dos Goiases), que fora transferido para a região de Borda do Mato.

A repartição das terras do novo descoberto do Rio Pardo fora realizada em 7 de julho de 1772 , por carta enviada ao Tenente Guarda Mor Francisco José Machado, pelo Morgado de Mateus. Na ordem de repartição e ocupação das terras consta:

[...] que se devem continuar na repartiçam dessas terras mineraes, segurança dos Reaes Direitos, e conservação da antiga posse dos limites dessa Capitania [...] e de todo movimento, ou novidade que houver por parte de Minas que fação prontos, e claros, avisos. (AESP, 1896, p. 163).

0 registro seria mudado mais uma vez ainda, em 1778, para o córrego São Mateus, atual região de Caconde, como nos esclarece Adriano Campanhole (1979). Essa alteração figura no mapa de José Joaquim da Rocha, do mesmo ano (Figura 5).

Pela documentação descrita acima, percebemos o papel estratégico da colocação dos Registros sobre os novos descobertos: se por um lado a intenção era de tomar para si os novos achados auríferos, em território paulista por direto (parte do termo da vila de Mogi-Mirim), a ação do Morgado de Mateus consiste em utilizar dos registros para afirmar a fronteira paulista na região, contribuindo para possíveis dilatações da região de litígio, se fossem necessárias. A ordem expressa para informar sobre a atuação do governo de Minas na região, deixa claro o caráter volátil do novo descoberto, pois não havia de modo algum a garantia da posse perpétua desse território. Vemos, portanto, que a noção de território caminha paralela à conquista militar estratégica na região, que consistia muito provavelmente na única garantia para a fixação populacional e manutenção da fronteira.

O ouro descoberto na região do Sertão do Rio Pardo iria se esgotar rapidamente. Outras lavras de ouro em Caconde seriam descobertas na década de 176026, esgotando-se no início do século XIX, culminando no que Adriano Campanhole chamou de "decadência da freguesia".

A decadência da freguesia se acentua, em virtude do falecimento do vigário em fins do século XVIII, transferindo-se a paróquia para a vila de Cabo Verde (o padre não tinha vigário adjutor, e a freguesia era de sua inteira responsabilidade), estando dessa forma o território de Caconde ligado em termos civis à Capitania de São Paulo e, eclesiasticamente, vinculada à Freguesia de Cabo Verde, como o "bairro rural do Bom Sucesso" (Campanhole, 1979, p.165). Esse fato necessita de um maior destaque dentro da perspectiva da rede urbana: a ligação com Minas Gerais, pela paróquia de Cabo Verde não se fez de forma oficial, pois as autoridades mineiras não tomaram posse da freguesia de Caconde. 0 que ocorreu foi a aceitação pela população, da administração dos sacramentos pelo vigário da paróquia de Minas, que ocorreu de forma despretensiosa e digamos, não oficial27.

\footnotetext{
26 Outra notícia de ouro descoberto na região de Caconde, no córrego Bom Sucesso, data de 20 de agosto de 1765, em carta endereçada ao governador de Santos, pelo Sargento Jerônimo Dias Ribeiro. Sobre esse assunto ver Adriano Campanhole (1979).

${ }^{27}$ Sobre esse assunto, consultar a obra de Adriano Campanhole.
} 
A decadência da freguesia de Caconde, e sua ligação à Cabo Verde, enquanto bairro rural28 nas últimas décadas do século XVIII, impõe a necessidade de criação de nova freguesia no Sertão do Rio Pardo. Assim em 3 de dezembro de 1805 é criada a freguesia de Nossa Senhora da Conceição da Franca, com a transferência da freguesia de Caconde para essa localidade, cuja jurisdição abrangia todo o território entre os rios Pardo e Grande, divisa com a capitania de Minas Gerais (Bacellar \& Brioschi, 1999). Mais uma vez, a nova freguesia é criada sob a invocação de Nossa Senhora da Conceição, padroeira de muitas das capelas curadas constantes no Sertão do Rio Pardo.

Antes da criação da freguesia de Franca, em dezembro de1805, havia sido solicitado por carta, em 6 de agosto do mesmo ano, de Hypolito Antonio Pinheiro, morador do "Bello Sertão da Estrada Goyas", que argumenta haver necessidade de criação de uma nova freguesia dentro daquele território, em virtude [...]

[...] do maior desamparo em que se vem, do Pasto Espiritual, por cuja falta querem voltar desconsolados os muitos intrantes que aqui vinhão se estabelecer: sendo este o motivo de fazerem o incluso requerimento ao Exmo. e Rvmo. Sr. Bispo suplicando-lhe queira facultarIhes o poderem crear huma nova Freguesia dentro destes Limites, por ser totalmente penoso o marcharem primeira, e segunda vez quarenta, the cicoenta legoas para a Freguesia de Mogi quando hajão de dar Estado a seus filhos, sujeito esta jornada a quatro portos reaes, além do perigo de Gentilidade barbara (AESP, 1896, p. 453).

Pela carta, percebe-se a falta de "Pasto Espiritual" aos suplicantes, o que indica que a freguesia de Nossa Senhora da Conceição do Bom Sucesso do Rio Pardo (Caconde) estaria realmente desativada, sem pároco que pudesse administrar os sacramentos. Dirigiam-se os habitantes, como informa o suplicante, à freguesia de Mogi, para os batizados de seus filhos.

\section{Uma rede fundiária em transição: permanências e rupturas nos status urbanos do século XIX}

A migração de mineiros no início do século XIX foi responsável pela povoação da nova freguesia de Franca. Acompanhando o movimento de expansão da pecuária e da agricultura em sentido oeste, que deve ser compreendido não exclusivamente como consequência do declínio da extração aurífera, novos habitantes irão se fixar no Sertão do Rio Pardo pela concessão de sesmarias. As grandes dimensões das sesmarias requeridas evidenciam sua finalidade para atividades agropastoris, de uma população em sua quase totalidade originária da Comarca do Rio das Mortes.

Para Lucila Reis Brioschi, o início do século XIX marcaria pela primeira vez, a ocupação desvencilhada da estrada dos Goiases. "Expandiu-se, dessa maneira, o cenário da feitura de posses, fabricação de roças e abertura das fazendas de gado e mantimentos, cujo processo tivera início com as primeiras sesmarias no século XVIII" (Brioschi, 1995, p. 116). De fato, a grande extensão das sesmarias solicitas no século XIX, antes de proibidas as concessões em 1822, dão a ver a velocidade na marcha de expansão no nordeste paulista, movida em grande parte por atividades agropastoris que requereram grandes regiões entre $\operatorname{rios}^{29}$.

\footnotetext{
28 O vigário responsável pela freguesia de Caconde, bem como todo o Sertão do Rio Pardo fora desde 1775 o padre Bueno de Azevedo. Adriano Campanhole, em sua pesquisa nos livros de óbitos da Sé, relata que o vigário era responsável por administrar os sacramentos desde a estrada de Jacuí a Rio Grande, a dali à Estrada de Goiás. Praticava os atos religiosos nos pousos de Rio das Pedras, Ribeirão do Inferno, Calção de Couro, Monjolinho, Vieira, Salgado, João dos Reis, Bagres, Paciência, Batatais, Carlos Barbosa, Rafael e Cubatão, até chegar à freguesia de N. S. da Conceição do Bom Sucesso do Rio Pardo (Campanhole, 1979, p. 159). 0 padre iria falecer em 1799, ficando a freguesia sem pároco responsável. Segundo o mesmo, em "1799 o padre Antônio João de Carvalho, vigário de Cabo Verde, ia a Caconde prestar assistência religiosa e celebrar o santo sacrifício da missa. Os fregueses de Caconde, falecido o seu vigário, passaram a ser fregueses daquela localidade" (Campanhole, 1979, p. 159).

${ }^{29}$ Em nossa pesquisa de mestrado, em andamento, podemos localizar as sesmarias concedidas no território da então freguesia de Caconde, em 1821, e que hoje correspondem ao município de São José do Rio Pardo. Tratam-se das sesmarias concedidas ao Capitão Alexandre Luiz de Mello e seus filhos (Arquivo Público do Estado de São Paulo, livro de Provisões, Patentes e Sesmarias no 41, fl. 160 - 161v.) localizadas na região "entre rios", dos cursos do Ribeirão Claro, Guaxupé, Fartura e Rio do Peixe, todos tributários do Rio Pardo. Dessas sesmarias, originou-se o núcleo urbano de São José do Rio Pardo. Outras também puderam ser localizadas, concedidas ao vigário de Cabo Verde, padre Ignácio do Prado e Siqueira (Arquivo Público do Estado de São Paulo, livro de Provisões, Patentes e Sesmarias no 41, fl. 159 - 159v.), que revelam, entre outras particularidades, a ação possessória ocorrida nessas terras, como método de imposição de uma rede urbana.
} 
No período entre 1804 e 1814, motivada pelo crescimento rápido da freguesia de Franca, o termo da vila de Campanha (criada em 1798 durante o governo de Bernardo José de Lorena) irá cobiçar o território do Sertão do Rio Pardo, pretendendo anexá-lo à sua jurisdição. Segundo Cláudia Damasceno Fonseca "essas terras foram, de fato, cobiçadas por diversas autoridades de Minas: pelos oficiais da câmara de Campanha, pelo ouvidor do Rio das Mortes e pelos juízes do julgado de Jacuí" (2011, p. 202).

Em 1814 são criadas as últimas vilas do período colonial em território mineiro: São Carlos de Jacuí e Santa Maria de Baependi, com territórios desanexados da vila de Campanha (Figura 3). A intenção da vila de Jacuí em anexar o território da freguesia de Franca não foi atendida, e a resposta da capitania de São Paulo sobre a investida mineira foi a criação de mais duas freguesias no termo da vila de Mogi-Mirim: Casa Branca (1814) ao sul do Rio Pardo e Batatais (1815) ao norte até o Rio Sapucaí-mirim. Segundo Lucila Reis Brioschi, [...]

[...] a criação das três freguesias em intervalo de tempo de dez anos expressava um crescimento demográfico que, aparentemente, não era acompanhado pelo aumento do nível de riqueza, uma vez que os paroquianos não estavam em condições de oferecer o "do que viver com decência" a seus vigários (Bacellar \& Brioschi, 1999, p. 79).

A desativação da freguesia de Caconde, e sua transferência para Franca, em 1805, deixaria muitas dúvidas sobre o ocorrido. A criação da freguesia de Casa Branca, para Adriano Campanhole, esclarece os complicados limites:

O alvará régio de 15 de março de 1814, criando a freguesia de Casa Branca na estrada de Goiás, apenas declarou como limite para a mesma, desde o Rio Jaguari até o pouso de Cubatão, sem determinar os confins laterais, pelo que prevalecia a divisão de 1775, dada por D. Frei Manuel da Ressurreição (Campanhole, 1979, p.269).

Somente em 1820 a freguesia de Caconde seria restaurada, por provisão do padre Carlos Luiz de Mello, em 1822 (Campanhole, 1979, p. 182). Carlos Luiz de Mello, ordenado padre em 1819, e responsável pela restauração da freguesia de Caconde, era filho de Alexandre Luiz de Mello, Capitão de Ordenanças de Minas Gerais, na vila de Campanha da Princesa e proprietário de grande quantidade de terras, obtidas por carta de sesmaria.

Em nossa pesquisa pudemos localizar, no Arquivo Público de Casa Branca, o documento de confirmação da restauração da freguesia de Caconde. Trata-se de um documento de 1846, elaborado pelo Juízo Municipal de Casa Branca, naquele momento vila, cuja única freguesia era Caconde. Assim, juridicamente, Caconde estava subordinada ao termo da vila de Casa Branca, onde foi lavrado o documento intitulado: "Autos de reconhecimento do patrimônio doado à Matriz da freguesia de Caconde a requerimento do fabriqueiro da mesma, Joaquim Alviz Moreira" (Arquivo Público de Casa Branca, fl. 1). 0 documento foi feito com o objetivo de registrar a segunda doação ao patrimônio da freguesia de N. S. da Conceição do Bom Sucesso do Rio Pardo, que foi feita da seguinte forma ${ }^{30}$ :

Diz Joaquim Alviz Moreira, morador da freguesia de Caconde, na qualidade de fabriqueiro da igreja matriz da freguesia que é padroeira Nossa Senhora da Conceição, a quem Miguel da Silva Teixeira, e sua mulher Maria Antônia dos Santos doaram o patrimônio de um quarto de légua em quadra, de terreno, só com a [ilegível] e direito de eles, [ilegível] e sua família poderem fazer suas casas de morada, sem pagarem aforamento algum, como tudo consta no título de doação passado a 28 de dezembro de 1822 [...] e ainda em virtude do mesmo título de doação, já consta edificada a Matriz, cercada de casas e já formam um arraial de povoação, unida em meio do terreno doado tendo no local um [ilegível] para a existência da igreja matriz e assim já se acha bem explorado todo o terreno do adro e sua confrontações até partes já sido medido a corda dois anos mais ou menos, cujo terreno de um quarto de légua em quadra, no tempo em que foi doado no Estado de Certão Inculto" (Arquivo público de Casa Branca, patrimônio doado à freguesia de Caconde - Reconhecimento, fls. 1-2) (grifo nosso).

\footnotetext{
${ }^{30}$ Atualizamos a ortografia do documento preservando, contudo, todo o teor da redação.
} 
Constitui um fato singular a doação para o restabelecimento da freguesia, pelo fato de uma freguesia ter sido "desativada" e também por ter ocorrido uma segunda doação, de "um quarto de légua em quadra" para a constituição de seu patrimônio. Pela descrição da povoação, intuímos tratar-se apenas do adro da igreja, construída antes da doação, e de casas confrontantes "medidas a corda", alinhadas com o mesmo. A escritura original de doação encontra-se no mesmo processo, assinada em 28 de dezembro de 1822, pelo vigário Carlos Luiz de Mello, tendo como uma das testemunhas seu pai, Alexandre Luiz de Mello.

Apesar da decadência do ouro, no início do século XIX, a freguesia, assim como todo o Sertão do Rio Pardo, aumentaria em população, devido à expansão agropecuária e da lavoura mista que, como afirmou Lucila Reis Brioschi, não guardavam relação com a decadência da mineração. As novas sesmarias solicitadas nas regiões de grandes bacias hidrográficas - como é o caso do Rio Pardo, apontado anteriormente - denotam a variedade de atividades no nordeste paulista na virada do século. Segundo a autora:

De Ouro Fino a Desemboque, toda a área a leste do Caminho de Goiás esteve sob tensão durante os séculos XVIII e XIX. Os 'avanços' dos mineiros sobre o território paulista durante o século XVIII prenunciaram o movimento migratório que imprimiu as suas marcas na área das futuras freguesias de Franca, Batatais e Casa Branca no início do século XIX. (Bacellar \& Brioschi, 1999, p. 53).

A freguesia de Franca foi elevada à vila em 1821 com o nome Vila Franca d'El Rey, cuja câmara fora instalada somente em 1824, quando passou a se chamar Vila Franca do Imperador. Batatais foi elevada à condição de vila em 1839, e Casa Branca em 1841, em um movimento em sentido sul, culminando na reconfiguração do nordeste paulista (Figura 6).

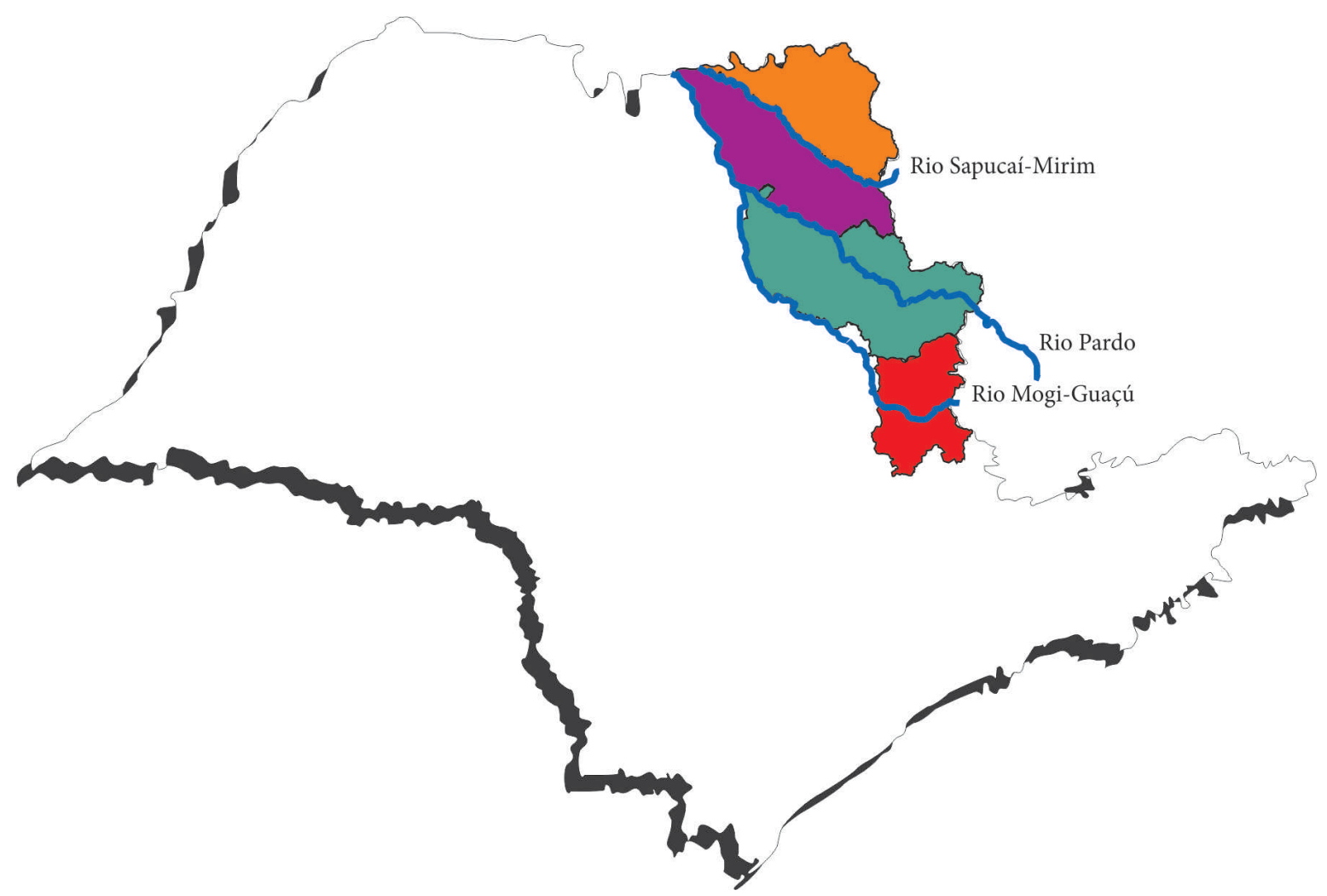

Figura 6. Mapa demostrando em 1841, os termos das vilas de Franca (1821) em laranja; Batatais (1839) em roxo, Casa Branca (1841) em verde e Mogi Mirim (1769) em vermelho. Os limites dos termos foram estabelecidos tendo como referencial a hidrografia dos Rios Sapucaí-Mirim, Pardo e Mogi-Guaçu. Fonte: Elaborado pelos autores sobre mapa atual da Divisão Municipal do IGC, disponível em: http://www.igc.sp.gov.br/produtos/divisao_municipal.html — Acesso em 23 mar. 2016.

Dessa forma, a elevação de Casa Branca à vila, em 1841, não deve ser vista como um fato isolado, mas uma resposta à dinâmica incisiva de dilatação das fronteiras, zonas de litígio entre duas 
províncias: São Paulo e Minas Gerais. A definição de seu território foi uma resposta imediata ao avanço mineiro em direção ao território paulista.

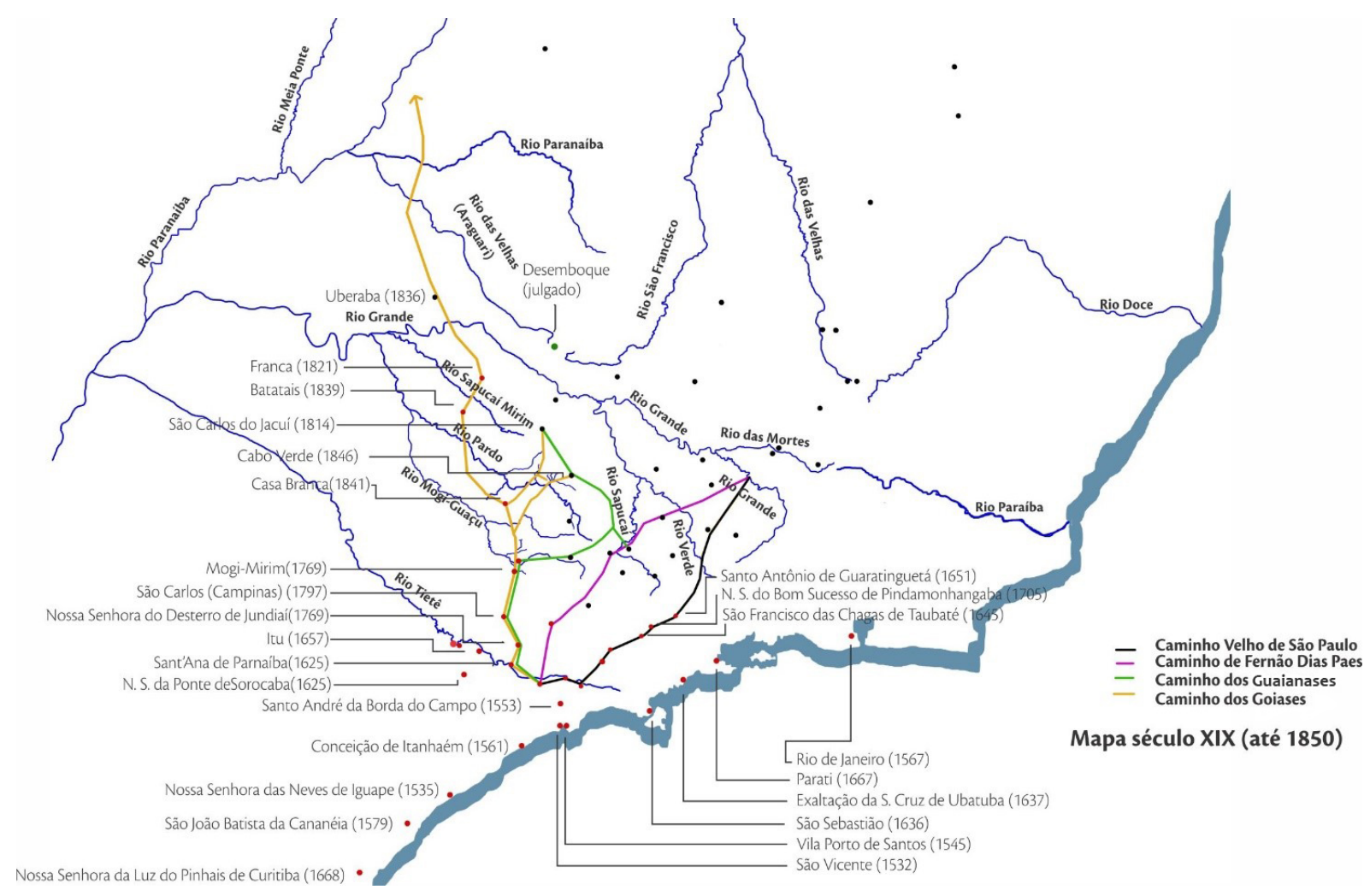

Figura 7. Mapa demonstrando a rede urbana em formação, no século XIX, até 1850.. Estão destacadas, além da rede de caminhos e trilhas apontados nos mapas anteriores, as últimas vilas criadas no nordeste paulista, em meados do século XIX. O ritmo de criação de novas centralidades, pelos termos das vilas paulistas, aumentou se comparado com a rede mineira, praticamente consolidadas. Destaque para as vilas de Franca (1821), Batatais (1839) e Casa Branca (1841), nascidas dos primitivos pousos no caminho do Anhanguera, tiveram papel fundamental na definição do território paulista. Fonte: Elaborado pelo autores sobre base digital do IBGE (2009). Recuperado de: http://mapas.ibge.gov.br/ politico-administrativo/regionais - Acesso em: 22 mar. 2017.

O conflito entre as duas Províncias não iria cessar com a criação das novas vilas. Nos Documentos Interessantes, outros casos são relatados sobre as tentativas de anexação dos termos paulistas, pelos mineiros:

Logo depois da independência circularam nos distritos de Franca e Batatais abaixoassinados pedindo a anexação destas freguesias à província de Minas. Isto teria sido a realização do antigo sonho mineiro da divisa pelo Rio Pardo (AESP, 1896, p. 92).

Concluído o processo de independência do Brasil, em 1822, as sistemáticas de fundação de núcleos urbanos passariam por modificações significativas. A fixação de mineiros no nordeste paulista, desde a freguesia de Caconde, deu-se em grande parte pela simples posse de grandes extensões de terras. A grande concentração de terra em favor de um único proprietário iria definir o status fundiário no século XIX, com a posterior chegada do café, cujos efeitos ainda ecoaram no século XX. Sobre esse assunto, Carlos Bacellar comenta:

Em escala regional, a introdução e expansão da lavoura cafeeira no Nordeste Paulista levou, em termos práticos, a uma reorganização da rede fundiária, até então voltada para o abastecimento interno. A fisionomia do campo viria se alterar profundamente, quase que apagando os traços da economia anterior. Como característica principal de toda essa transformação de novas propriedades rurais, revertendo a tendência natural de fragmentação com o passar das gerações (Bacellar \& Brioschi, 1999, p. 93).

Instituímos o marco da Lei de Terras, em 1850, como um balizador para nosso estudo. Após essa data, e com a regulamentação da Lei de 1854, a lógica dos conflitos fundiários iria se transformar 
drasticamente. A lei estabelecia o fim das sesmarias, tornando a compra e venda o único modo de acesso à terra em todo o país e, mais do que isso, impunha condições que tornariam extremamente favorável a introdução do imigrante como força de trabalho, sem contudo, permitir seu acesso à terra.

Para Thomas Holloway (1984) o controle dos recursos fundiários significa poder público, uma medida de status social pela riqueza produzida pela terra. Durante o período colonial, a Coroa concedeu grandes áreas aos indivíduos por meio do estatuto das sesmarias, o que para o historiador, foi "usado muito mais para atender propósitos políticos da Coroa do que para promover a real ocupação das zonas rurais" (Holloway, 1984, p. 172). Na realidade, as sesmarias raramente foram demarcadas e ocupadas; a nova lei de 1850 legislava sobre as chamadas terras devolutas e proibia, definitivamente, a concessão de terras por sesmarias e o princípio da posse na ocupação e uso da terra. No interior paulista, em geral, a legislação teve pouca eficiência, continuando a posse como o instrumento usual de apoderamento de terras.

A intensificação do processo de interiorização, deu-se, segundo Ghirardello, após a Lei de Terras (1850), e a consequente formação de patrimônios religiosos, de onde se abririam novos caminhos, "em direção às propriedades rurais da redondeza e outros povoados importantes" (2010, p.43).

As comunicações por caminhos, tidos como fundamentais à expansão de um capital cafeeiro interiorizado, eram mantidos e incentivados pela Assembleia, representada pela mesma elite que, localmente, era responsável pelo crescimento da franja produtora no novo oeste paulista.

Em resumo, pensava-se na construção das estradas de ferro até as áreas produtoras e a partir daí estradas e caminhos convergentes de forma mais capilar, situação que realmente se deu em São Paulo até as primeiras décadas do século XX (Ghirradello, 2010, p. 45)

A lavoura incipiente e a criação dos patrimônios religiosos estarão sempre à frente da ferrovia, ao menos de 200/300 Km: "algumas dezenas de aventureiros, de criminosos exilados do convívio social, precediam, com fundação de pequenos aglomerados, de arraiais ou de pequenos burgos, o verdadeiro povoamento, que viria 20,30 ou 40 anos depois (Ellis Junior, 1951, p. 386-7 apud Ghirardello, 2010, p. 48).

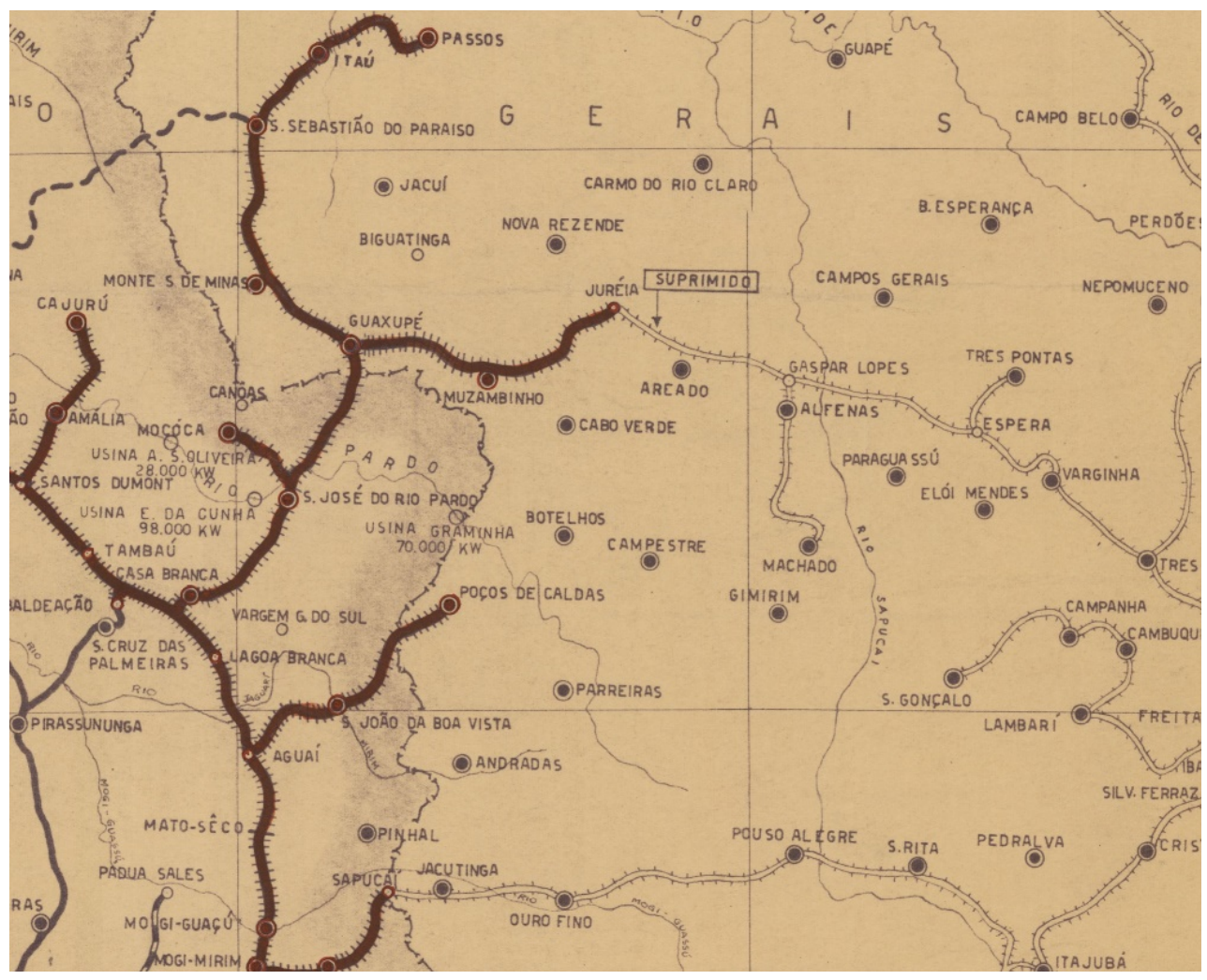

Figura 8. Recorte sobre o "Mapa das linhas da Companhia Mogiana de Estradas de Ferro e sua situação em relação às outras linhas", cópia de 1962. Em vermelho no mapa, a linha da Mogiana, que na segunda metade do século XIX se sobrepôs aos antigos caminhos, a estrada do Anhanguera e suas derivações. A oeste da fronteira estão marcadas algumas linhas férreas mineiras, e sua intersecção com a Mogiana. Fonte: Arquivo Público do Estado de São Paulo. 
No mapa da Figura 8, demostramos a rede ferroviária da Companhia Mogiana, iniciada na segunda metade do século XIX. O município de Caconde não possuía ferrovia, era servido pelo município vizinho de São José do Rio Pardo. A sobreposição das redes é evidente: alguns trajetos das ferrovias mineiras ainda esboçavam a rede de caminhos iniciada no século XVIII. Ademais, podemos dizer que a paisagem se forma pela deposição dos vários "sedimentos" históricos, onde a ferrovia se apropriou de antigas rotas consolidadas.

É pela sobreposição dos vários caminhos, apontados aqui desde o século XVIII, que o nordeste paulista pode construir seu território como um dos instrumentos de definição das fronteiras entre São Paulo e Minas. Nesse aspecto, o papel da freguesia de Nossa Senhora da Conceição do Bom Sucesso do Rio Pardo, hoje Caconde, foi peça fundamental dentro de uma política iniciada com o Morgado de Mateus que consistia em fixar a população dispersa pelo território. A paisagem, fruto de todos esses processos descritos no presente trabalho, ainda guarda os referenciais pela geografia, toponímia, caminhos e rotas (atuais rodovias, muitas vezes) e propriedades que nasceram enquanto pontos nodais dentro da rede urbana.

\section{Conclusão}

Pelo presente trabalho, podemos aplicar os conceitos construídos sobre um recorte espacial e temporal, demostrando a formação de uma parcela do nordeste paulista. A sobreposição das redes deu-se de forma a preservar os antigos referenciais contidos na paisagem, fruto dos processos de construção territorial em diferentes séculos. Retomamos a definição de Milton Santos sobre a rede urbana ao examinar os novos processos de formação territorial no século XIX: reconstituir a formação da rede urbana, desde meados do século XVII, nos permitiu entender as conexões estabelecidas e a importância dos diferentes pontos nodais dentro de uma rede de relações humanas, cuja espacialização define a rede urbana.

Quando à paisagem do nordeste paulista, esta formou-se por um acúmulo de tempos; o tempo geológico e físico que resultou na transformação da paisagem natural, e o tempo histórico, que imprimiu na paisagem os processos de formação territorial. Nesse caso, a metáfora de uma sedimentação nos parece apropriada, uma vez que a sobreposição de várias redes sobre uma mesma base natural, resultou em uma paisagem que só pode ser compreendida em perspectiva transtemporal.

As mudanças no século XIX em relação ao XVIII ocorreram principalmente em relação à fundação de novos núcleos urbanos, agora não mais ligados à um santo de devoção, patrimônio religioso, mas sim a um patrimônio laico, empreendido por novos "plantadores de cidades", usando a expressão de Pierre Monbeig. Perduraram, contudo, muitos patrimônios religiosos durante a segunda metade do século XIX, perdendo-se no início do século XX com a figura dos loteadores e novas formas de parcelamento do solo.

O estudo da arqueologia da paisagem tem se mostrado um caminho seguro, na identificação da formação territorial como também para a adoção de medidas de preservação em escalas macrorregionais. Nesse sentido, pesquisas como essa abrem caminhos para estudos que privilegiam a identificação cultural fora dos regionalismos que perpetuaram por décadas visões parciais, de uma história que não pode ser segmentada, no intuito de compreender a formação do território e consequentemente, da estruturação da sociedade.

\section{Referências}

Arquivo do Estado de São Paulo [AESP] (1896) Documentos interessantes para a história e costumes de São Paulo, Divisas de São Paulo e Minas Gerais. (11) São Paulo: Typografia. Recuperado de: http:// bibdig.biblioteca.unesp.br/bd/bfr/or/10.5016_10-ORDCISP-06-11_volume_11/\#/190/

Arquivo Público de Casa Branca (1846). Patrimônio Doado à Freguesia de Caconde - Reconhecimento, Casa Branca, 11p.

Bacellar, C. de A. P., \& Brioschi, L. R. (Orgs.) (1999). Na Estrada do Anhanguera: uma visão regional paulista. São Paulo: Humanitas FFLCH/USP. 
Brioschi, L. R. (1995). Criando História; paulistas e mineiros no nordeste de São Paulo, 1725-1835. 266 folhas. (Tese de doutorado). Universidade de São Paulo, Programa de Pós Graduação em Sociologia, da Faculdade de Filosofia, Letras e Ciências Humanas, São Paulo, SP, Brasil.

Bueno, B. P. S. (2009). Dilatação dos confins: caminhos, vilas e cidades na formação da Capitania de São Paulo (1532-1822). Anais do Museu Paulista. s/n., São Paulo, pp. 251-294.

Bueno, B. P. S. (2016). O Brasil-Colônia: em que medida mais urbano do que parece à primeira vista? In Actas Primer Congreso Iberoamericano de Historia Urbana, Santiago de Chile, pp. 825-834.

Campanhole, A. (1979). Memória da Cidade de Caconde: freguesia antiga de N. S. da Conceição do Bom Sucesso do Rio Pardo. São Paulo: A. Campanhole.

Corrêa, L. (1989). A rede urbana. São Paulo: Editora Ática.

Derntl, M. F. (2010). Método e arte: criação urbana e organização territorial na capitania de São Paulo (1765-1811). (Tese de Doutorado). Universidade Estadual de São Paulo, Faculdade de Arquitetura e Urbanismo, São Paulo, SP, Brasil.

Fonseca, Cláudia Damasceno (2011). Arraiais e vilas d'el rei: espaço e poder nas Minas setecentistas (M. J. G. Teixeira, \& C. D. Fonseca, Trads.). Belo Horizonte: Editora UFMG.

Ghirardello, N. (2010). A formação dos patrimônios religiosos no processo de expansão urbana paulista (1850-1900). São Paulo: Ed. UNESP.

Holloway, T. H. (1984). Imigrantes para o café: café e sociedade em São Paulo, 1886-1934 (E. Malheiros, Trad.). Rio de Janeiro: Paz e Terra.

IBGE (2009). Recuperado de: http://mapas.ibge.gov.br/politico-administrativo/regionais

Jucá Neto, C. R. (2012). Primórdios da Urbanização no Ceará. Fortaleza: Edições UFC; Editora Banco do Nordeste do Brasil.

Marx, M. (1991). Cidade no Brasil: terra de quem? São Paulo: Nobel; Editora da Universidade de São Paulo.

Monbeig, P. (1984). Pioneiros e Fazendeiros de São Paulo. São Paulo: Editora Hucitec; Editora Polis.

Reis, N. G. (2013). As minas de ouro e a formação das Capitanias do Sul. São Paulo: Via das Artes.

Reis, N. G. (2014). 0 caminho do Anhanguera (1a. ed.) [Beatriz Cannabrava, Trad./versión en español]. São Paulo: Via das Artes.

Santos, M. (2002). A Natureza do Espaço: Técnica e Tempo, Razão e Emoção. São Paulo: Edusp. 